\title{
Armorican arrowhead biographies: Production and function of an Early Bronze Age prestige good from Brittany (France)
}

\author{
Clément Nicolas ${ }^{1}$, Colas Guéret ${ }^{2}$ \\ 1. UMR 8215 Trajectoires, Maison de l'Archéologie et de l'Ethnologie, 21, allée de l'université 92023 Nanterre \\ Cedex France. Email: clement.nicolas@wanadoo.fr \\ 2. Equipe Ethnologie préhistorique, UMR 7041 ArScAn, Maison de l'Archéologie et de l'Ethnologie 21, allée de \\ l’université 92023 Nanterre Cedex France. Email: colas.gueret@hotmail.fr
}

\begin{abstract}
:
Brittany can pride itself on the Armorican arrowheads found in Early Bronze Age graves (2150$1700 \mathrm{BC})$. In the present state of knowledge, these are the only specialized craft products in knapped flint produced in this region at the western edge of continental Europe. Admired since the 19th century, these flint arrowheads have never really been studied. Due to the wealth of graves and gravegoods, a relatively precise study can be undertaken of the development of these craft products, despite the low number of reliable radiocarbon dates.

These arrowheads are characterized by a well-defined type (pointed tang and oblique barbs) most often combined with ogival form. Raw materials show the selection of a high quality yellow translucent flint, of which the origin has to be sought at more than 400 kilometers (Lower Turonian flint from Cher Valley). From a technical point of view, Armorican arrowheads reveal a great mastery of retouch by pressure-flaking. This skill is written in stone by the perfection of forms, the extreme thinness (until 2,5 mm thick) and very long barbs (until $25 \mathrm{~mm}$ long). Such work could not have been done without the use of copper, even bronze, awls. Moreover, some marks may testify to the implication of these tools. On 549 arrowheads that have reached to us, none of them presents diagnostical impact features. However, use-wear analysis indicates that most of them were hafted (adhesive traces, bright spots, blunt edges). These facts suggest that they are less functional arrowheads than objects for the show. In the graves, Armorican arrowheads are frequently set down carefully in wooden boxes taking the shaft off.

The Armorican arrowheads with their exotic raw materials, their high-degree of technicality, and their absence of use, have all features of a prestige good. They have been discovered by dozens in few graves under barrows with very rich funeral items (bronze daggers decorated with golden pins, precious bracers, silver beakers, etc.). According to these obvious facts, they symbolize the power of the elites. The genesis of Armorican arrowheads are in all likelihood explained by a climate of increasing social competition, which express itself in Brittany by an individualization of burial rites, a development of metalworking and a reorganization of territories.

In this article, we will stress on raw materials selection, technology and know-how, as well as use-wear analyses. All these approaches will help us to trace the biographies of the Armorican arrowheads.
\end{abstract}

Published by the School of History, Classics and Archaeology, University of Edinburgh ISSN: 2055-0472. URL: http://journals.ed.ac.uk/lithicstudies/

This work is licensed under a Creative Commons Attribution 2.5 UK: Scotland License. 
Keywords: Armorican arrowhead; flint; Britanny; France; Early Bronze Age; technology; use-wear analysis

\section{Introduction}

Brittany can pride itself on productions of outstanding projectile points, the Armorican arrowheads, recovered from Early Bronze Age tombs (2150-1600 BC). More than one thousand tumuli are known from this period in Brittany but only 32 yielded Armorican arrowheads (Figure 1). From the neighbouring regions, three further graves have contained Armorican arrowheads but they are located quite far from the core area in western Brittany: around ten arrowheads in Fosse-Yvon barrow (Beaumont-Hague, Manche, Normandy), six in Loucé barrow (Orne, Normandy) and one in the passage tomb of Tumulus de la Motte (Pornic, Loire-Atlantique, Pays-de-la-Loire). The arrowheads from these three graves are not examined in this article (some could have been imported from Brittany, others could be local imitations).

In most cases, the Breton graves with Armorican arrowheads were covered by cairns or huge tumuli that may measure $6 \mathrm{~m}$ in height and $60 \mathrm{~m}$ in diameter. The grave architecture greatly varies: megalithic slabs used for the covering or the walls, straight or vaulted drystone walls, wooden features, coffins or floors occurring in multiple combinations. Generally, the acid soil conditions dissolved all the skeletal remains except for a few cases which confirm that the graves of the Early Bronze Age were individual burials although rare double or triple burials are known.

In all, 762 arrowheads were discovered in these tombs from Brittany; frequently tens and up to 60 specimens were present in the same grave. Nonetheless, only 549 pieces have been preserved, the others have been lost, stolen or modified for other purposes (assembled on a jewel or used as a lighter stone during the 19th century; Lukis, 1886; Bertrand, 1891).

In the burials, very abundant grave goods, seemingly placed in wooden boxes, accompanied the Armorican arrowheads (Prigent, 1880, 1881; Martin \& Berthelot du Chesnay; Martin \& Prigent, 1907; Briard, 1970). The most striking example is certainly the deposit of numerous daggers made of copper alloy (up to ten in a single grave). Fair preservation conditions permitted the survival of organic remains such as the scabbards of the daggers thanks to the presence of metal oxides. Personal ornaments of distant origin were also discovered in these burials: pendants and wrist guards made from Baltic amber (Gardin, 1996), wrist guard made from Whitby jet (Yorkshire, Northern England; Needham, 2009), gold or silver spiral chains, probably of Iberian origin, and pendants made from jadeite originating from the Monte Viso area (Italy; Nicolas et al., 2013). In summary, tombs including Early Bronze Age arrowheads are rare, monumental and richly equipped. For these reasons, they were identified as being burials of Early Bronze Age chiefs in Brittany (Briard, 1984).

The Armorican arrowheads are present in exceptionally high numbers in the burials of these elites. This raises a question about the status of these projectile points: were they ordinary arrowheads or specific productions? What makes them particular? Their shape, their material or the way they were manufactured? Were these arrowheads strictly funerary offerings or were they everyday implements? Were they used, and, if this is the case, for what purposes? In sum, were these prestige items? In order to answer all these questions, we developed multiple approaches based on typology, the study of raw materials, technology and use wear analyses, with the aim of tracing their biographies, from their manufacture to their use and finally their deposit in the graves. In addition, the important number of burials and 
accompanying grave goods makes it possible to develop a rather detailed picture of the evolution of this craft despite the small number of reliable radiocarbon dates.
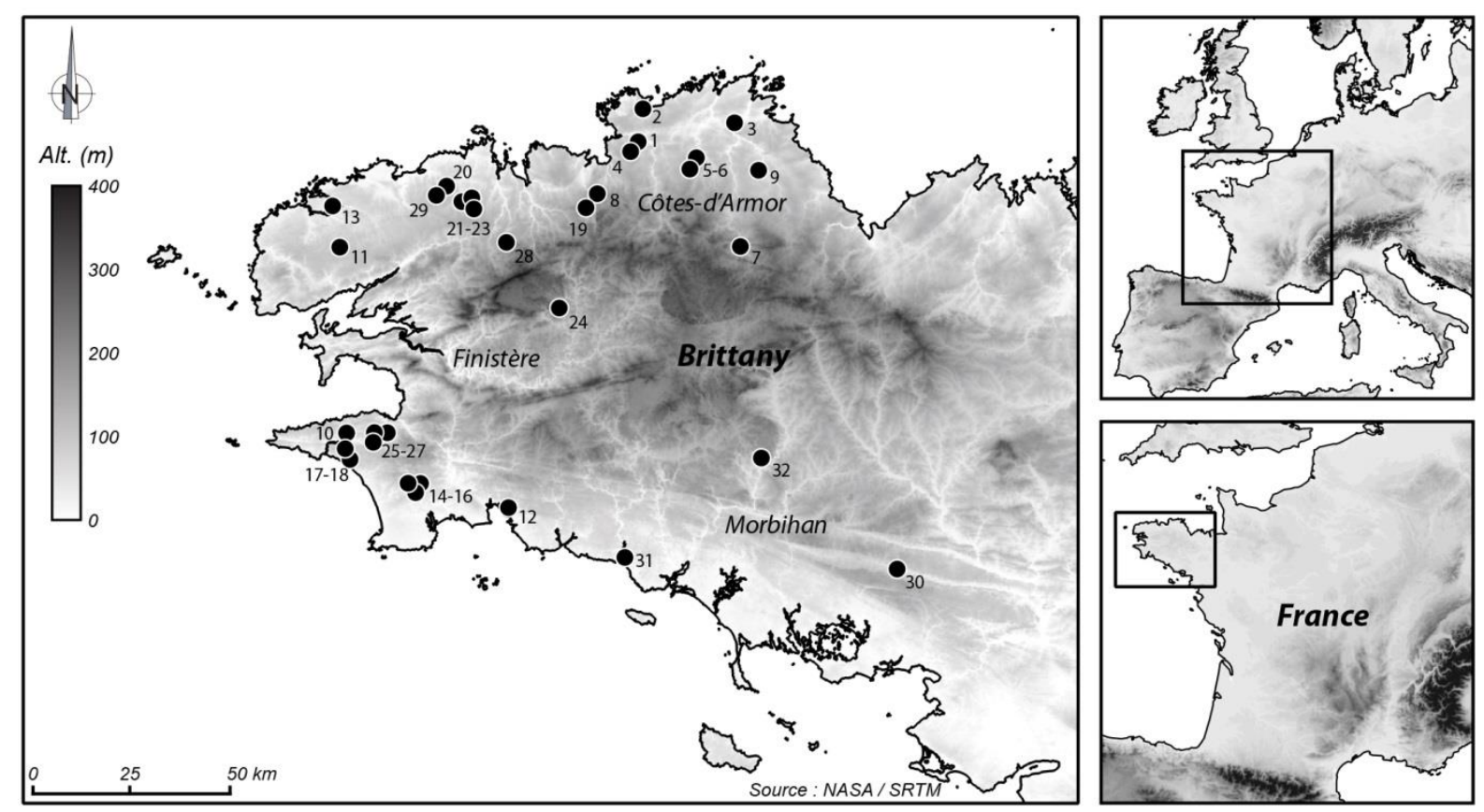

Figure 1. Distribution map of the Early Bronze Age graves including Armorican arrowheads in Brittany (mapping C. Nicolas). Côtes-d'Armor: 1. La Motta, Lannion; 2. Crec'h-Perros, Perros-Guirec; 3. Mouden-Bras, Pleudaniel; 4. Rumédon, Ploumiliau; 5. Tossen-Kergourognon, Prat; 6. Tossen-Rugouec, Prat; 7. Brun-Bras, Saint-Adrien; 8. Porz-ar-Saoz, Trémel; 9. Tossen-Maharit, Trévérec; Finistère: 10. Kerodou, Beuzec-Cap-Sizun; 11. Coatanéa, Bourg-Blanc; 12. Le Rhun, Concarneau; 13. Prat-ar-Simon-Pella, Lannilis; 14. Cosmaner, Plonéour-Lanvern; 15. Fao-Youen, Plonéour-Lanvern; 16. Kerhué-Bras, Plonéour-Lanvern; 17. Kersandy, Plouhinec; 18. Lescongar, Plouhinec; 19. Cazin, Plouigneau; 20. Goarillac'h, Plounévez-Lochrist; 21. Kernonen, Plouvorn; 22. Keruzoret, Plouvorn; 23. Lambader (?), Plouvorn; 24. Kerguévarec, Plouyé; 25. Kerlivit 2, Pouldergat; 26. Kervini Nord, Poullan-sur-Mer; 27. Kervini Sud, Poullan-sur-Mer; 28. Limbabu, SaintThégonnec; 29. Graeoc 2, Saint-Vougay; Morbihan: 30. Coët-er-Garf, Elven; 31. Cruguel, Guidel; 32. SaintFiacre, Melrand.

\section{Typology of the Armorican arrowheads}

The Armorican arrowheads are characterised by oblique barbs associated with a pointed tang, except for some cases in which the tang is rounded or substituted by a concave base (Briard \& Giot, 1956; Nicolas, 2013). Only a few arrowheads were found out of grave context: at present, six specimens have been recorded. They are rather small and match the smallest ones discovered in the burials (Figure 2).

We distinguished nine different types based on the shape of the tang or of the concave base, to the overall shape of the arrowhead (concave triangular, triangular, sub-triangular, ogive-shaped, pointed horseshoe arch shape), the length/width ratio and the length of the barbs (Nicolas, 2011, 2013; Figure 3 \& Table 1).

The short and medium shapes (Rumédon, Cazin, Kerguévarec, and Kernonen types) are by far the most numerous (Figure 4, a). The elongated ogive-shaped arrowheads (Kervini, Limbabu, Graeoc types) show a clearly differentiated distribution in that the arrowheads with long barbs (Limbabu and Graeoc types) are clustered in the north-western part of Finistère (Figure 4, b). This picture suggests the existence of several production places in Brittany. Finally, the triangular arrowheads (Cruguel and Keruzoret types) occur in small numbers (18) and do not show a particular distribution pattern (Figure 4, c). 


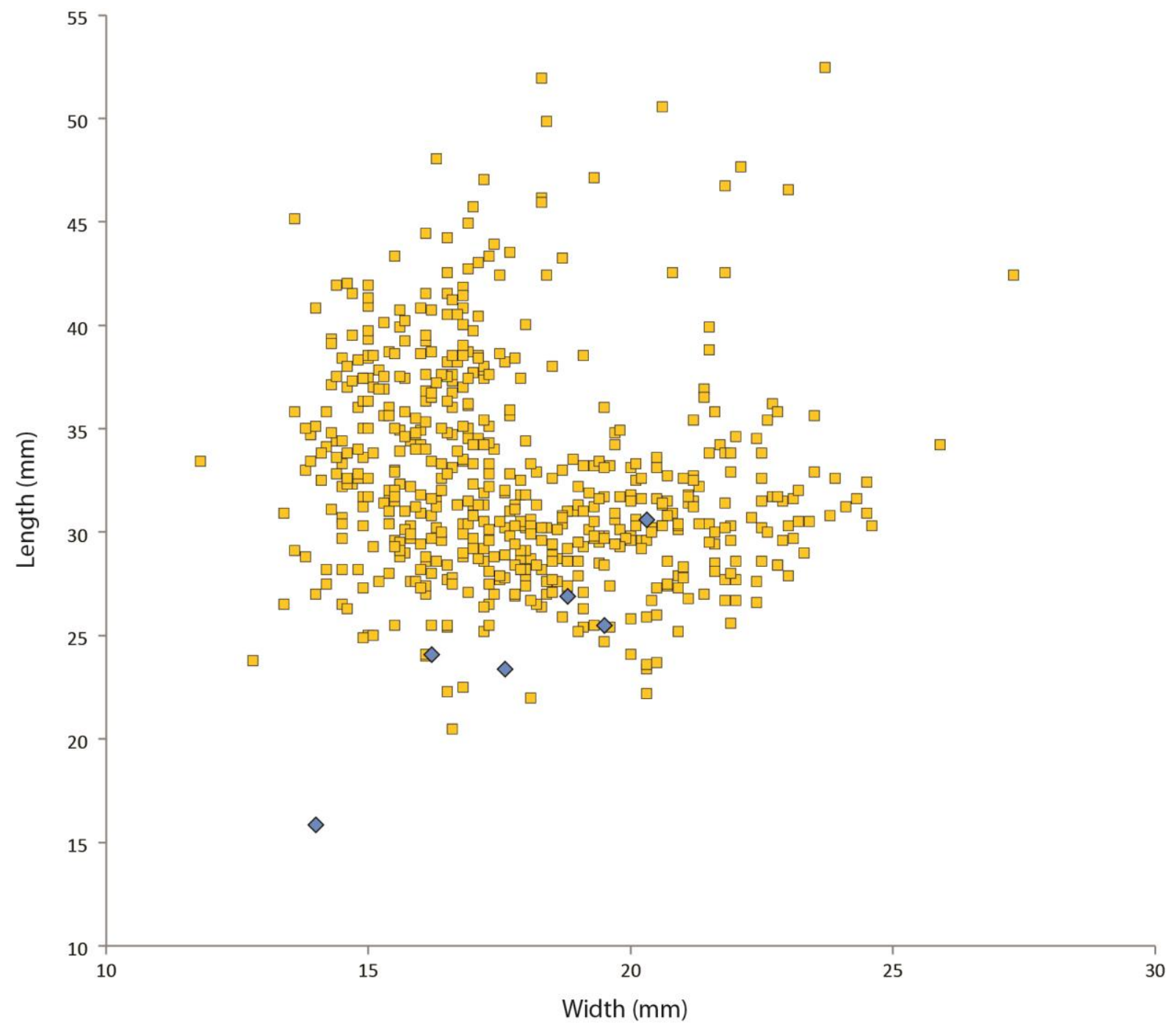

$\square \quad$ Arrowheads found inside the graves

$\diamond \quad$ Arrowheads found outside the graves

Figure 2. Comparison between arrowheads found inside and outside the graves.

\section{Typo-chronology}

The Armorican arrowheads derived quite clearly from the main type of Bell Beaker arrowheads (ca. 2500-2000 BC) with squared tang and squared barbs, that are found in most part of the Western Europe (Nicolas, 2013; Bailly, 2014). We know some intermediary arrowheads with pointed tang and squared barbs or with squared tang and slanted barbs, found both in late Bell Beaker burials and graves of the beginnings of the Early Bronze Age, illustrating a short sequence of elaboration of the Armorican type from the Bell Beaker arrowheads (Nicolas, 2011a, 2013).

The abundant material recovered from the burials including arrowheads enabled Stuart Needham (2000) to propose an initial seriation of these graves. Based on our arrowhead typology and taking into account distinct regional variability, it was possible to further refine this typo-chronology (Nicolas, 2013). It was possible to recognise three stages illustrating the continuous evolution of the Armorican arrowheads (Figure 5). During stage 1, the short and almost triangular pieces (Cazin type) tend to develop towards short (Kerguévarec and Rumédon types) or medium ogive-shaped arrowheads (Kernonen type). During stage 2, the ogive-shaped arrowheads are elongated and distinct types show long barbs (Limbabu and Graeoc types). During stage 3, the arrowheads are triangular in shape with a tang (Cruguel 
type) or alternatively a concave base (Keruzoret type). Two specimens made from copper alloy may be interpreted as being imitations of flint arrowheads (Figure 5).

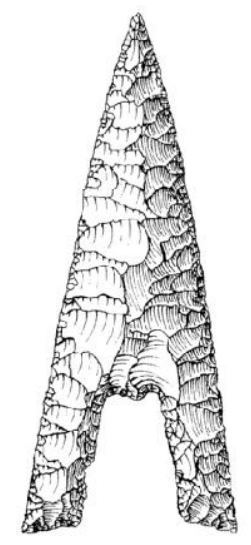

Keruzoret type

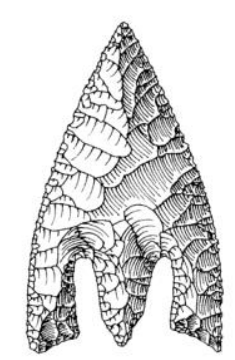

Kernonen type

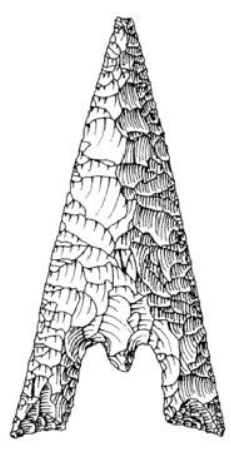

Cruguel type

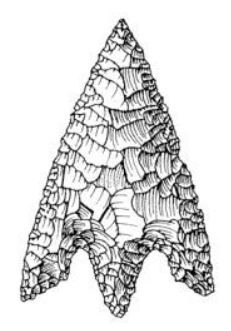

Cazin type

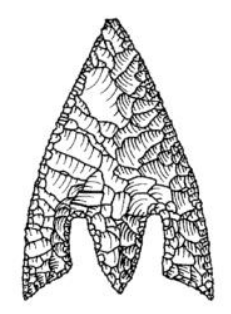

Kerguévarec type

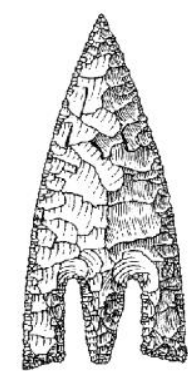

Kervini type

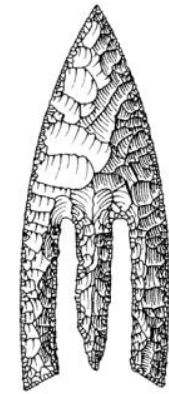

Limbabu type

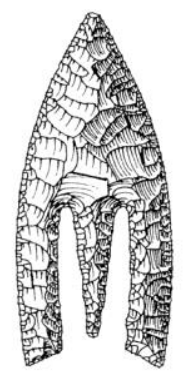

Graeoc type

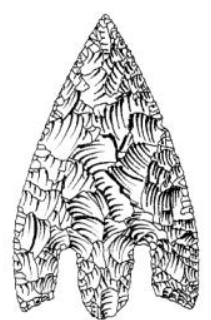

Rumédon type

Figure 3. Types of Armorican arrowheads (drawings C. Nicolas).

Table 1. Typology and inventory of the arrowheads found in the Early Bronze Age grave from Brittany.

\begin{tabular}{|c|c|c|c|c|c|}
\hline Type & Tang & Form & $\begin{array}{c}\text { Ratio } \\
\text { length/width }\end{array}$ & $\begin{array}{l}\text { Length of the } \\
\text { barbs }\end{array}$ & $\begin{array}{l}\text { Total } \\
\text { number }\end{array}$ \\
\hline Keruzoret & None & triangular & $2-3$ & - & 8 \\
\hline Cruguel & Pointed & $\begin{array}{l}\text { concave triangular to } \\
\text { triangular }\end{array}$ & $1,5-3$ & - & 9 \\
\hline Cazin & Pointed & sub-triangular & $1-2$ & $<12 \mathrm{~mm}$ & 20 \\
\hline Kerguévarec & Pointed & ogive-shaped & $1-1,49$ & $<12 \mathrm{~mm}$ & 93 \\
\hline Kernonen & Pointed & ogive-shaped & $1,5-1,99$ & $<12 \mathrm{~mm}$ & 192 \\
\hline Kervini & Pointed & ogive-shaped & $2-3$ & $<12 \mathrm{~mm}$ & 82 \\
\hline Limbabu & Pointed & ogive-shaped & $2-3,5$ & $\geq 12 \mathrm{~mm}$ & 82 \\
\hline Graeoc & Pointed & $\begin{array}{l}\text { pointed horseshoe arch } \\
\text { shape }\end{array}$ & $2-3$ & $\geq 12 \mathrm{~mm}$ & 3 \\
\hline \multirow[t]{5}{*}{ Rumédon } & Rounded & $\begin{array}{l}\text { Subtriangular to ogive- } \\
\text { shaped }\end{array}$ & $1-2$ & $<12 \mathrm{~mm}$ & 10 \\
\hline & & & & Other type & 8 \\
\hline & & & & Undefined & 111 \\
\hline & & & & Unknown & 144 \\
\hline & & & & Total number & 762 \\
\hline
\end{tabular}



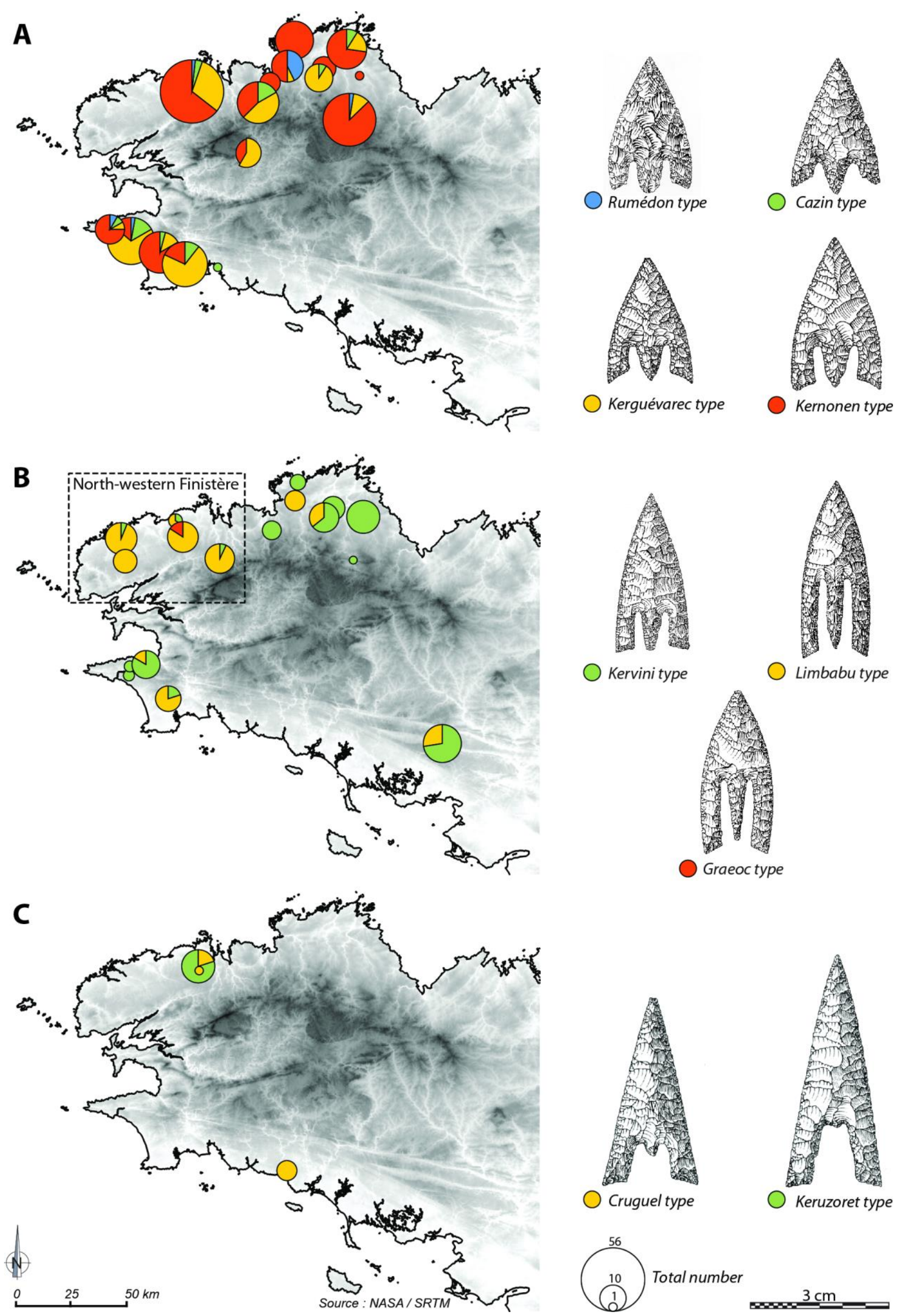

Figure 4. Distribution maps of the different types of Armorican arrowheads (map \& drawings C. Nicolas). 


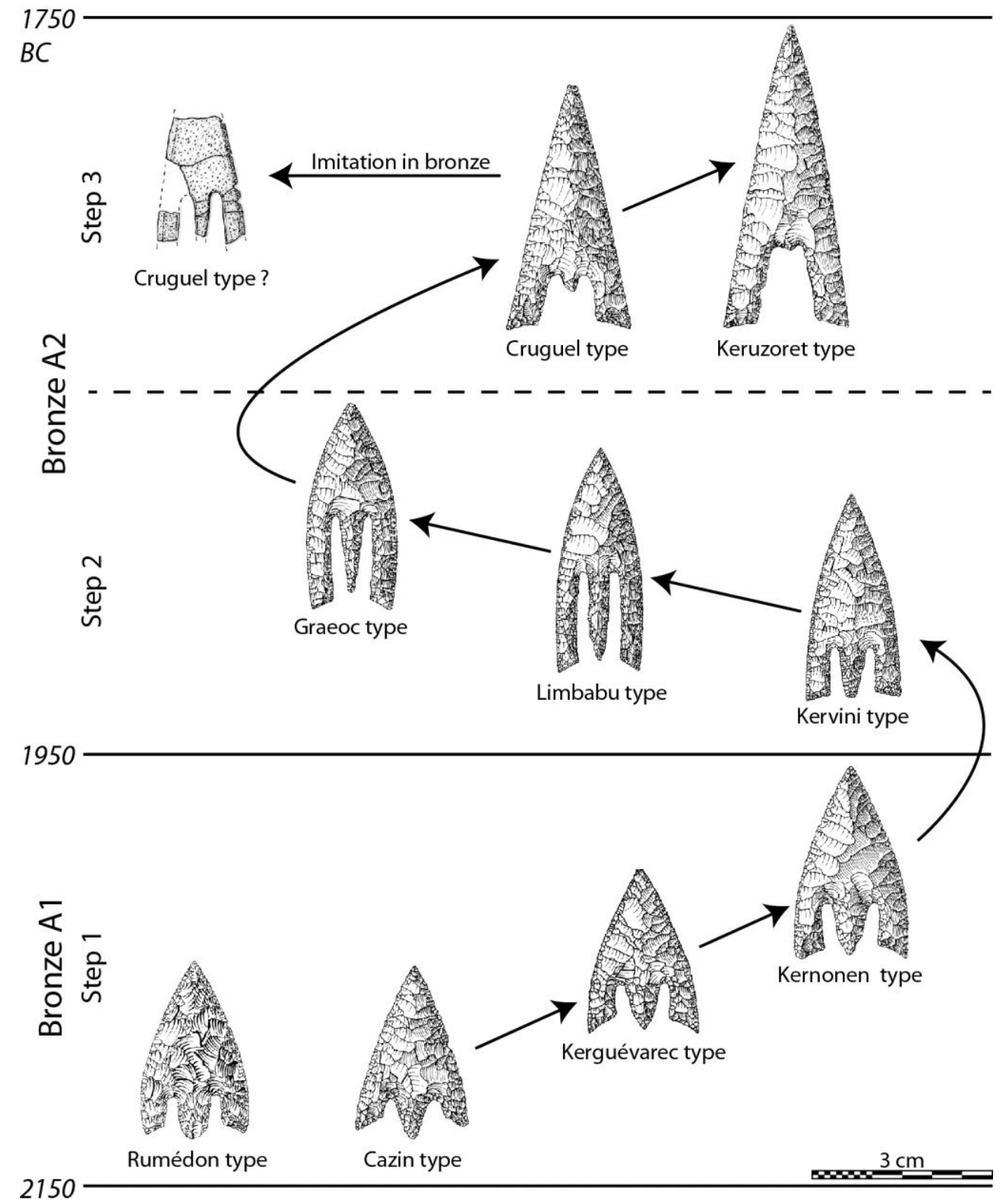

Figure 5. Evolution of the Armorican arrowheads (drawings C. Nicolas).

Three reliable and precise radiocarbon dates are available which do not challenge the general pattern of this seriation. Stage 1 is dated by the burial of Brun-Bras (Saint-Adrien, Côtes-d'Armor; Briard, 1978) to $3650 \pm 35$ BP (GRN-7176), i.e. between 2137 and 1929 cal. BC $(95.4 \%)$. Stages 2 and 3 cannot be subdivided and seem to be contemporaneous. These dates range between 2016 and 1771 cal BC (95.4\%) and they stem from the barrow of Crec'h-Perros (Perros-Guirec, Côtes-d'Armor; $3542 \pm 22$ BP, UBA-11989; personal communication with Henri Gandois), attributed to stage 2, and from the grave of Saint-Fiacre (Melrand, Morbihan; $3555 \pm 35$ BP, SUERC-30676; communication with Alison Sheridan), attributed to stage 3 . Stages 1 and $2 / 3$ overlap by almost one century because of the inaccuracy of radiocarbon dating. To put it simply, stage 1 can be dated between 2150 and $1950 \mathrm{BC}$ and stages 2 and 3 between 1950 and $1750 \mathrm{BC}$. This subdivision fits the chronology established for Southern Germany and Switzerland distinguishing Bronze A1 and A2 (Voruz, 1996; Hafner and Suter, 2003), as well as the chronology established for the British Isles (Needham et al., 2010). 


\section{The raw materials}

The Armorican arrowheads show the use of a large variety of raw materials. It was possible to record 25 different facies ranging from translucent or semi-translucent colours (colourless, grey, honey-coloured, orange, red, brown) to more opaque colours (grey or honey-coloured).

During stage 1, almost all of these facies were employed but the use of translucent honey-coloured or dark honey-coloured flints and honey-coloured, red or grey semitranslucent flints was predominant. The best example of this diversity is the barrow of Kernonen (Plouvorn, Finistère; Briard, 1970) which yielded 60 arrowheads deposited at three spots within the burial. 30 arrowheads were made from opaque and translucent flint covering a wide range of colours from honey-coloured to orange, red, and pinkish and to grey and black (Figure 6). These arrowheads seem to have been placed in a wooden box.

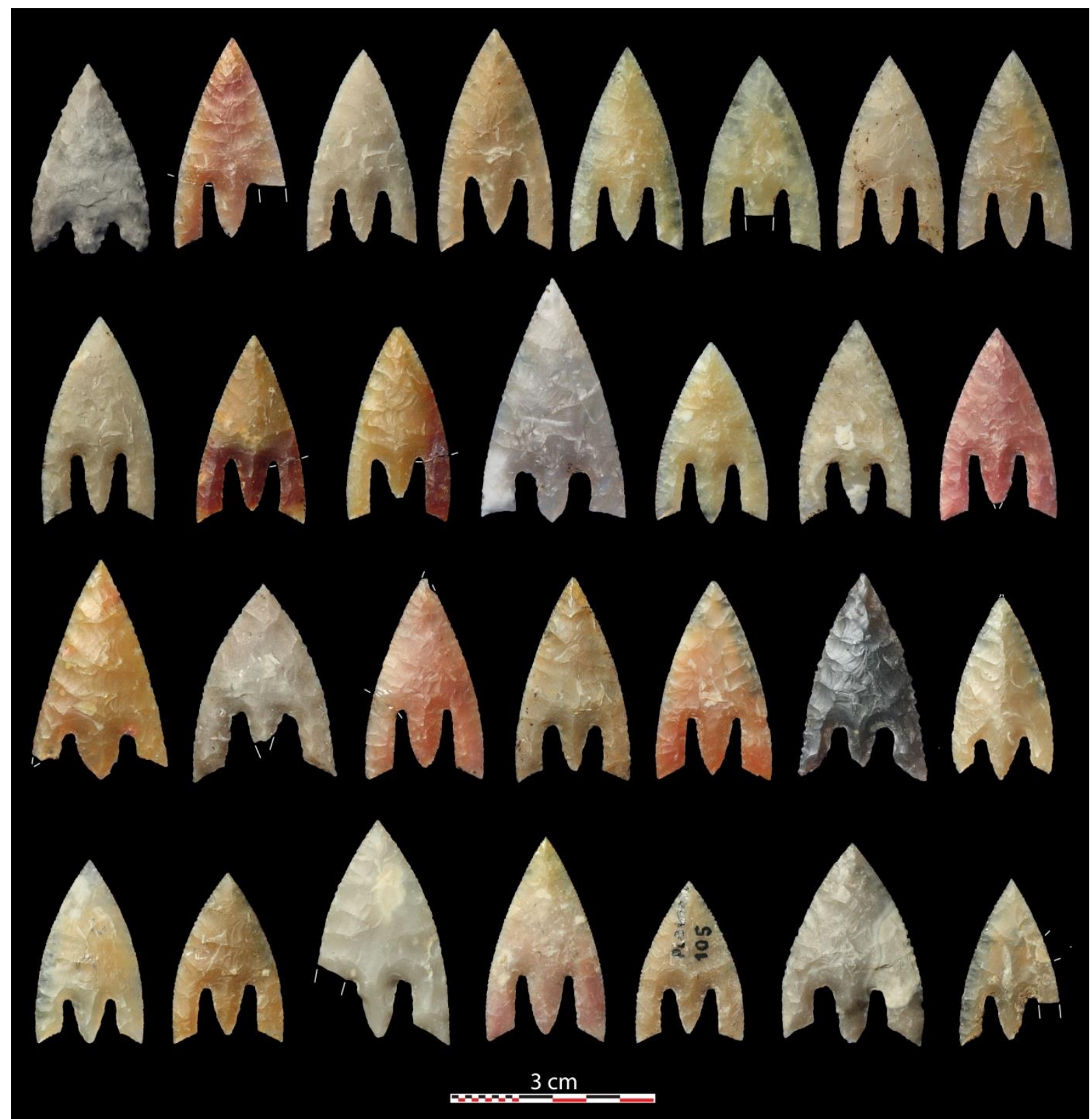

Figure 6. Arrowheads stemming from one of the wooden boxes found in the Kernonen barrow at Plouvorn, Finistère (photo C. Nicolas). 
During stage 2, this diversity of raw materials was severely restricted. The arrowhead series were much more homogeneous and were mainly manufactured from honey-coloured translucent flint $(64.4 \%)$. This proportion strongly increases when considering the only projectile points with long barbs of the Limbabu and Graeoc types stemming from the northwestern part of the Finistère: $82.3 \%$ of them were made of honey-coloured translucent flint, whereas $10.6 \%$ were manufactured from dark honey-coloured translucent flint, honeycoloured semi-translucent flint, grey- honey-coloured translucent flint or orange translucent flint. Simultaneously, in the remainder of Brittany, several assemblages are entirely or partially comprised of arrowheads made of grey flint, most often opaque but sometimes also translucent flints (Figure 7).

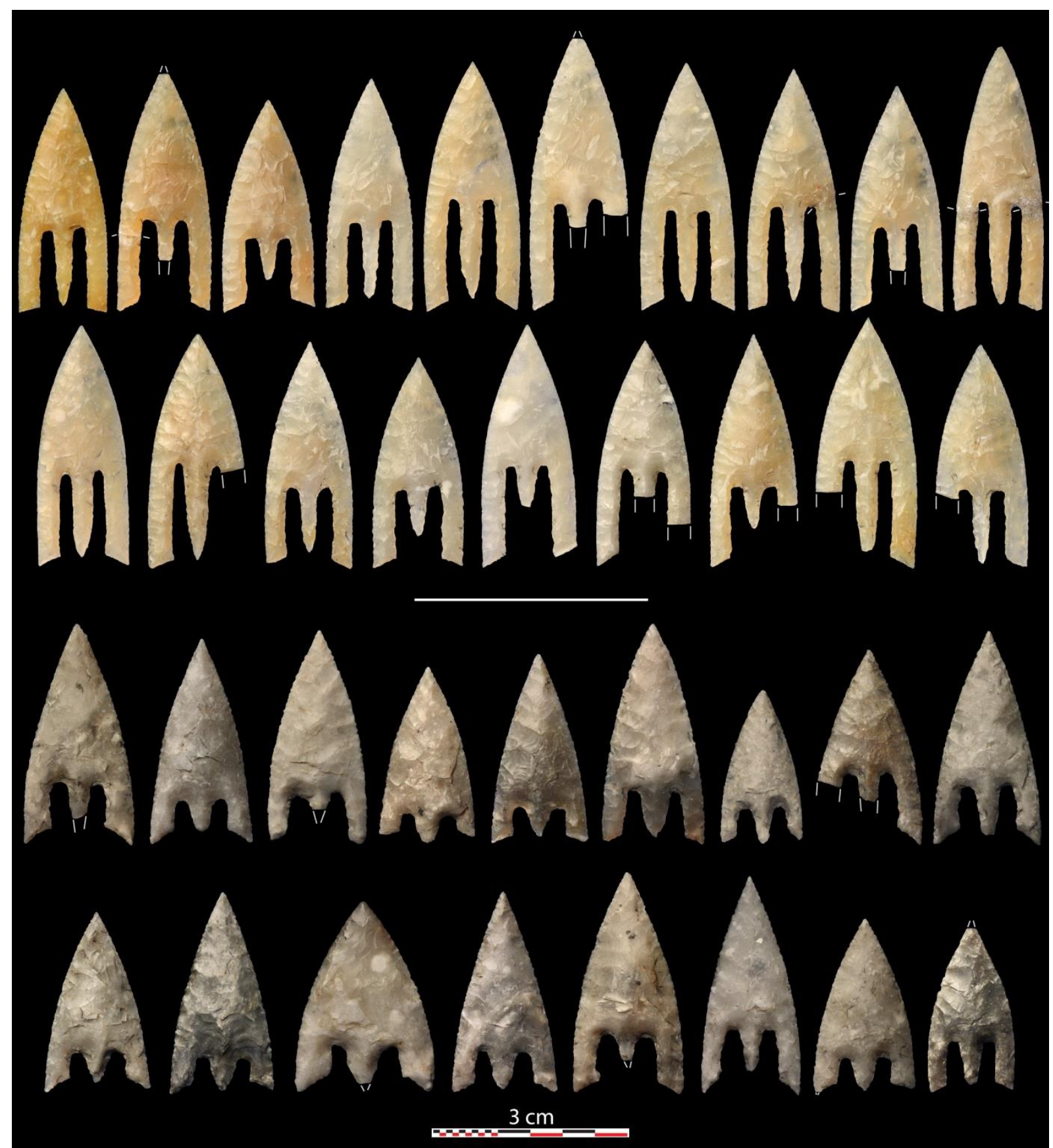

Figure 7. Arrowheads from the Limbabu grave at Saint-Thégonnec, Finistère (top) and from the Lescongar barrow at Plouhinec, Finistère (bottom) (photo C. Nicolas). 
During stage 3, the honey-coloured translucent flint remains predominant but it is invariably accompanied by a range of other types which are apparently only variations.

The large number of arrowheads made of honey-coloured translucent flint allows us to depict a wide-ranging picture of its characteristics. We are dealing here with fine-grained flint including various intraclasts. Calcareous inclusions are amongst the most numerous and they are smaller than $1 \mathrm{~mm}$, about $1 \mathrm{~mm}$ or even as large as $10 \mathrm{~mm}$. They occur in varying scatters and are sometimes completely absent from the matrix. Pinkish, red or violet zonation and more rarely colourless, black or orange ones can be recognised.

At first sight, it seems impossible that this fine-grained translucent honey-coloured flint stems from the Armorican massif that hosts not a single primary flint source (Marchand, 2012; Figure 7, top). Flint pebbles originating from the coastal belt exhibit similar colours but their texture is often coarser. Moreover, no cortex or subcortical zones were ever observed on the arrowheads which may support the hypothesis of local origin of the honey-coloured flint. We therefore have to turn towards flint sources located outside the Armorican massif. The eastern margins of this massif are at about $200 \mathrm{~km}$ from the main distributions of Armorican arrowheads: several types of honey-coloured translucent flint are found in the Paris Basin but its western part is imperfectly documented. The best element of comparison is the honeycoloured flint of Meusnes procured from the Lower Turonian levels in the Cher valley. This latter type occurs in various colours: honey-coloured, light brown, grey, greenish, black. An opaque zoned variety exhibiting bright colours, ranging from yellow to red, is also attested (Aubry, 1991, p. 106). It also contains the same types of intraclasts as the honey-coloured flint of the Armorican arrowheads (bryozoans, quartz microgeodes, manganese dendrites). The red-coloured variety is probably a patina due to a ferruginous impregnation in a context of terraces or detrital spreadings where a large amount of iron is flowing in the waters and the soils (Masson, 1981). Equally, the large number of raw material facies can probably be explained by the wide colour range of the Meusnes flint (Nicolas, 2012).

The honey flint from Meusnes and its possible variants are clearly the most common in the assemblages of Armorican arrowheads. Nonetheless, distinct translucent, semi-translucent or opaque flint types encountered do not match the description of the Meusnes flint. Most often this is high quality flint of probable Cretaceous origin the provenience of which could not be identified. The grey opaque flint types as well as distinct semi-translucent flint types of poor quality may have been recovered from gravel barrier on the coast (Figure 7, bottom). However, the absence of cortical zones makes it impossible to confirm this assumption. It was possible to identify several flint types that occur in anecdotic quantities: one arrowhead was knapped on rock crystal, three on Upper Turonian flint originating from the Grand Pressigny region and six specimens were probably manufactured from Bajocian or Bathonian flint stemming from the Anglin valley in the Vienne region (Fouéré, 1994; Primault, 2003).

Raw material was possibly procured in close proximity to the local sources: two arrowheads of honey-coloured flint present a small zone of beige-coloured fine and grained cortex, rather indicating procurement near the primary sources. However, the raw material could also have been procured further downstream. Lower Turonian flint blocks occur in the alluvium of the Cher River, and they were then transported by the Loire River up to the estuary at Saint-Nazaire (Loire-Atlantique). From there, the sea currents deposited small nodules along the Atlantic coasts. Pebbles with a maximum size of $10-15 \mathrm{~cm}$ can be observed in the gravel barriers of the Morbihan and the Pays-de-la-Loire. In the Loire estuary, the blocks still measure up to 40 or $50 \mathrm{~cm}$ (personal communication with Philippe Forré). These different possibilities of flint procurement do not necessarily exclude each other. The hypothesis of procurement in the Loire estuary seems attractive. This is the most important source containing high-quality material which is located the closest to Brittany. In addition, the Loire River drained the whole amount of flint pebbles encountered on its course and one 
of its tributaries, which may explain the variety of flint types used for the manufacturing of the Armorican arrowheads.

\section{Technology}

Reconstructing the operational sequence of the Armorican arrowheads is a difficult task because only finished, highly retouched products are known. For 25 arrowheads only it was possible to recognise the nature of their blanks: these are flakes originating from full debitage (18), cortical flakes (3), Kombewa flakes (3) and patinated flakes (1). The use of these supports varies just as much: the arrowheads are generally shaped in the direction of debitage (29) but also in the opposite direction (10) or used laterally (14). The production and the use of the blanks were apparently not determined by a strict operational scheme. The adaptation of the volume of the blank to the planned arrowhead seems to be important. No traces of heat treatment have been recorded, despite its frequent use in Prehistory for pressure-flaking. Some arrowheads are indeed red-coloured but this is most probably due to a coloured patina. Especially, no differences of brightness between blank and retouch have been recorded, which should be expected in case of heat treatment (Masson, 1981; Inizan \& Tixier, 2000).

The shaping of the Armorican arrowheads apparently starts with a preform made by soft organic percussion as is suggested by the small and scaled removals observed on several pieces. The shaping is then continued by pressure flaking, as is attested to by clearly concave first negatives of removal, fine and regular removals and sharp micro-overhangs left on either side of the pressure point (Pelegrin, 2004). The use of an awl made from copper alloy is demonstrated through the presence of small pressure points $(<1 \mathrm{~mm})$ and of slight greyish green traces left by unsuccessful retouch (Nicolas, 2013; Figure 8). The retouch types are generally covering $(91 \%)$ and more rarely invasive $(7.9 \%)$ or short $(1.1 \%)$. The most frequent combinations are parallel $(51.6 \%)$, transverse $(32.8 \%)$, multidirectional $(14.7 \%)$ or more rarely rippled $(0.9 \%)$. These different retouch combinations are generally present on the same assemblages of arrowheads (Figure 9). Most of the pieces manufactured in this way are perfectly biconvex. The edges were systematically regularised by particularly fine microretouch $(<2 \mathrm{~mm}$ long).

The most critical moment in the manufacture of an Armorican arrowhead is the knapping of the tang and the barbs. Each removal requires controlled pressure that is sufficient to remove the flake and to avoid overshot. The more the knapping progresses, the greater the risk of breaking the tang or the barbs: all efforts may be ruined by an unfortunate counterblow by the compressor. Plunging marks, which occurred during notching or retouching, attest to the difficulty of this operation.

The shaping of the tang and the long barbs requires the use of high-quality material (honey-coloured flint of Meusnes) as well as sophisticated knapping in shaping an arrowhead that is both slender and thin; this is very well demonstrated by the Armorican arrowheads in the northern part of Finistère (Figure 10). We could state that the arrowheads in this sector had an elongated ogive-shaped form and long barbs during stage 2 of the Early Bronze age. They are extremely slender and thin, measuring generally between 2.6 and $4.1 \mathrm{~mm}$ in thickness. Only a few arrowheads of the Limbabu type measure between 4.2 and $5.3 \mathrm{~mm}$ in thickness. The long ogive-shaped arrowheads are clearly distinguishable from the shorter and thicker specimens of the preceding stage. It clearly appears that greater thickness was required in order to shape the tang and the long barbs by striking off longer blanks. During stage 3, the triangular, still elongated arrowheads become thicker but they are also characterised by the abandonment of the tang (Keruzoret type): as the preform was not thin enough, it was not possible to shape long barbs and tang. 


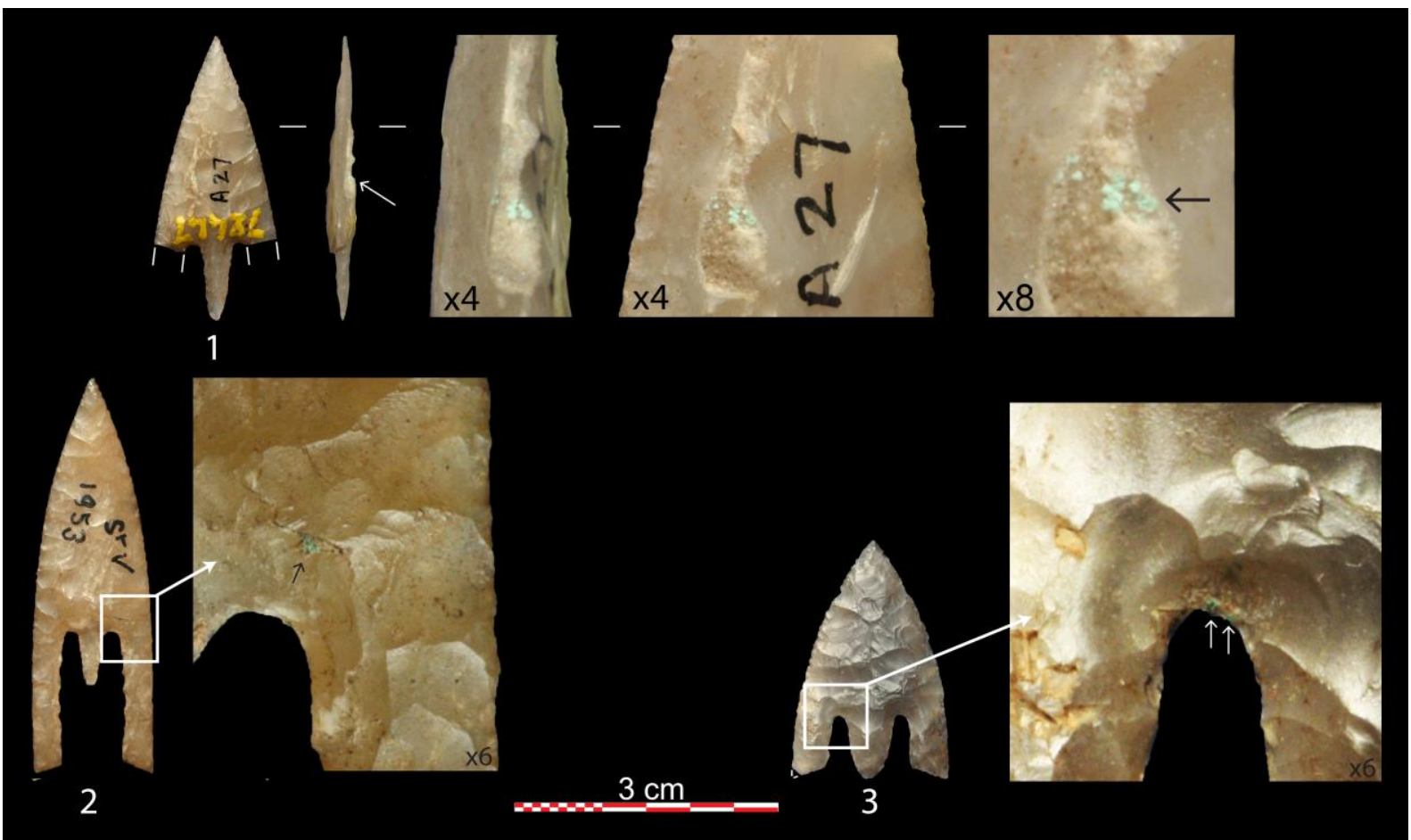

Figure 8. Greyish green traces on Armorican arrowheads indicating the use of copper (or copper alloy) awl for pressure-flaking (photo $\mathrm{C}$. Nicolas). These greyish green traces are located in key spots of the chaîne-opératoire. The first one (1) is located on a crystalline inclusion of the flint, which has hampered the pressure flaking. The knapper succeeded in removing the left part of the inclusion but removals stopped against the left part, leaving a step 1,4 mm thick visible on the profile. The knapper tried to remove it by pressure. By this way, he managed to do three removals, clearly visible by two concave beginnings. Below the second concavity, we could see two greyish green traces, indicating a last attempt to do a fourth removal. In the two other cases, the knapper should have tried to eliminate a hinged removal (2) or to correct a slight asymmetry of the spaces between barbs and tang (3). 1. Tossen-Rugouec, Prat, Côtes-d'Armor; 2. Graeoc 2, Saint-Vougay, Finistère; 3. Rumédon, Ploumiliau, Côtes-d'Armor.

\section{Craft specialization and organization of the production}

The Armorican arrowheads doubtlessly required a high level of skills in order to master all the stages of the operational sequence and to control pressure flaking with maximum accuracy. Experiments were carried out by Frédéric Leconte according to an operational sequence similar to the one observed on the archaeological pieces (Nicolas, 2013). These experiments revealed that a self-taught knapper after two years of daily practice will master the knapping of arrowheads with barbs of $12 \mathrm{~mm}$ length (Limbabu type) and of arrowheads with barbs of $16 \mathrm{~mm}$ length after several additional months of training. Yet, Frédéric Leconte was not a complete novice in flint knapping and he practised for about ten years (knapping mostly handaxe). Two to three years could be therefore the minimum time span to master the manufacturing of Armorican arrowheads. This apprenticeship period is certainly different from that of prehistoric times. The teaching provided by the knapping masters probably encouraged the progress of the apprentice. In Western Europe, few communities carry on high-skilled production of flint artefacts during the Bronze Age. The most famous example is the Danish flint daggers. We are dealing in both cases with bifacial technology of flint working but the size of products and the know-how required are different. Nonetheless, these flint daggers offer a good benchmark about craft specialization. The most striking pieces of Danish daggers require a high degree of know-how: preforms could be knapped by a skilled apprentice but the final pressure-flaking takes years of practice for a self-taught knapper 

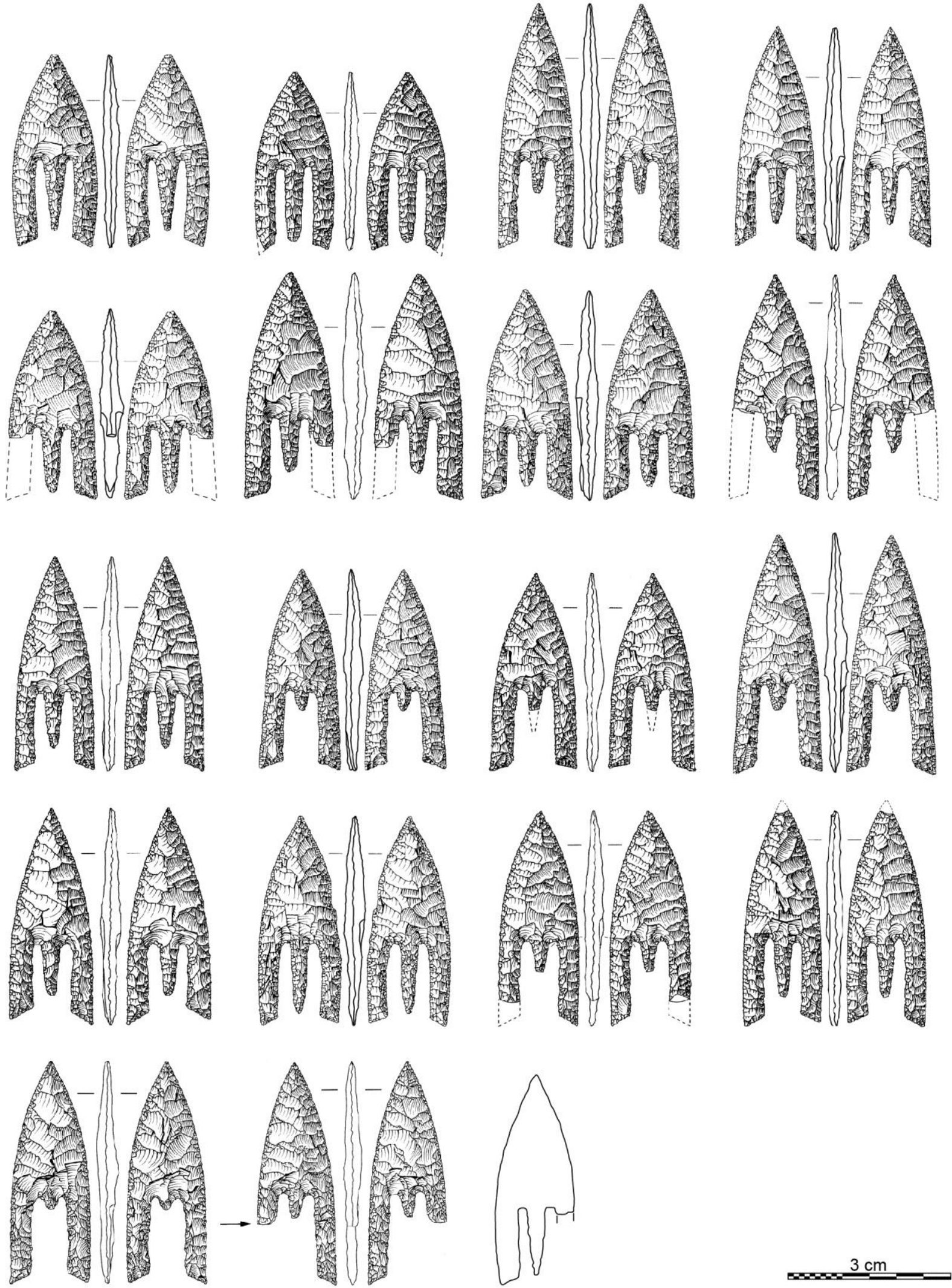

Figure 9. The arrowheads from Graeoc 2 barrow, Saint-Vougay, Finistère: an example of the variety of retouch with transverse, parallel or multidirectional retouch combination (drawings C. Nicolas). 
(Apel, 2001, 2008; Stafford, 2003). For imparting this technical tradition, Jan Apel (2001) proposed that the daggers production was based on an apprenticeship system and was the privilege of specific lineage or clan, as well as access to sources of flint of good quality and sufficiently large. This kind of organization could be effective for the production of Armorican arrowheads. Regarding to the raw materials, the acquisition of the translucent honey-coloured flint could have been done directly by the craftsmen of Armorican arrowheads venturing in areas not necessary friendly or by exchange involving a control on the quality and the volumetry of the flakes used as blanks.

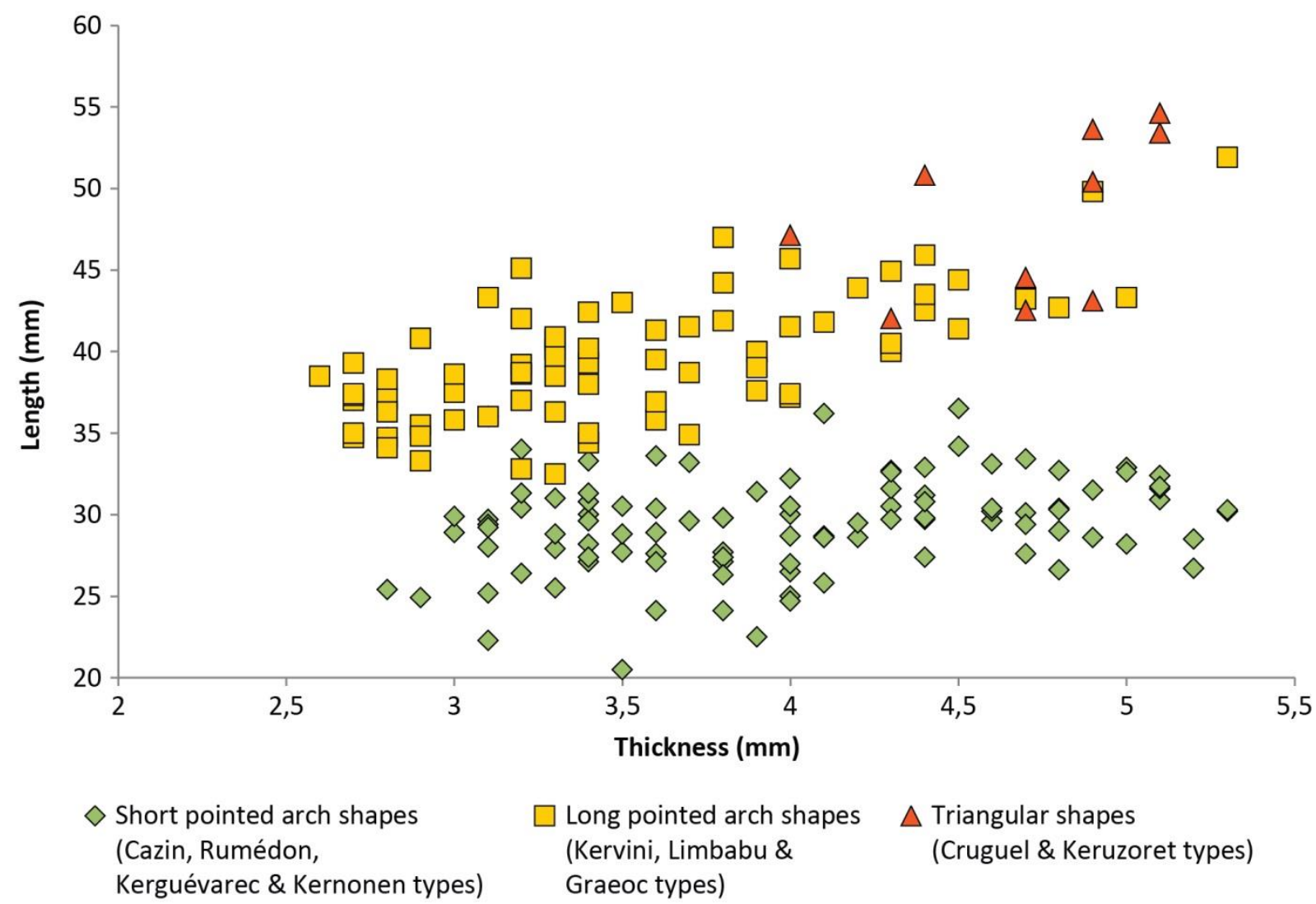

Figure 10. Diagram of the length/thickness ratio of the Armorican arrowheads from the northern part of Finistère.

As we know only the finished products in burials, it is impossible to reconstruct the whole chaine opératoire of the Armorican arrowheads and the ways of the organization of their production. The scarcity of Armorican arrowheads out of Brittany (except few exceptional finds in the neighbouring areas or coarse copies) indicates most probably a manufacture in this region not so far from the barrows of chiefs. Nevertheless, we know only few Early Bronze Age settlements and most of them have yielded a scarce lithic industry, excepted the dry-stone house of Beg ar Loued in Molène Archipelago (Finistère) where numerous flint pebbles from the coast have been knapped mainly by split percussion (Pailler et al., 2011). By the way, we have supervised several field surveys in northern Finistère in order to find Early Bronze Age domestic sites or workshops with elements of the chaineopératoire of the Armorican arrowheads. In the neighbouring (around $3 \mathrm{~km}$ ) of barrows with Armorican arrowheads (Figure 1, no. 13 and 29), two surface sites very similar (Langristin, Plounévez-Lochrist and Kerfricho, Lannilis) have yielded stone artefacts which could match with a Late Neolithic or an Early Bronze Age date: the lithic industry is characterized by direct or split percussion, a predominance of scrapers and a sandstone sharpener (supposedly for metal). The main feature in both cases is the presence of a yellow translucent flint, similar of the one used for the Armorican arrowheads, representing around $25 \%$ of the flints (other 
flints are mainly sea pebbles). This yellow translucent flint has been taken from deposits close to the primary sources (beige-coloured fine and grained cortex) or from rivers (smooth neocortex). Unfortunately, no pieces of this yellow translucent flint could match with the bifacial knapping of the Armorican arrowheads, even if tiny flakes (around 0,5 cm) have been collected. Furthermore, this yellow translucent flint has been knapped like the flint pebbles, by direct percussion with hard hammer or split percussion until little exhausted cores (around 2-3 cm). Only excavations could help in dating the import of this yellow translucent flint and its relationship or not with Armorican arrowheads production (Le Goffic, 1995; Nicolas, 2010, 2011b).

\section{Use wear analyses}

Use wear analysis with a stereo microscope and a metallographic microscope was carried out according to the conventional protocols used in this field (Keeley, 1980). Only three series of Armorican arrowheads stemming from Brun-Bras (Saint-Adrien, Côtes-d'Armor; Briard, 1978), Crec'h-Perros (Perros-Guirec, Côtes-d'Armor; Blanchet, 2005) and Prat-ar-SimonPella (Lannilis, Finistère; Le Goffic \& Nallier, 2008), in total 72 projectile points, corresponding to $14.3 \%$ of the entire corpus were investigated. However, this analysis was completed by macroscopic observations made on all the Armorican arrowheads that were preserved.

\subsection{Use wear analysis of the blanks testifying to the circulation of flake blanks?}

In three cases in which the original surface of the blank was preserved, this latter could be slightly distinguished from the negatives of removal. At Crec'h-Perros, the blank is characterised by a weak polish with loose to medium density and mat to bright polish more strongly marked on the higher points of the microtopography (Figure 11, no. 2). At Prat-arSimon-Pella, the extent of the polish is more intense and brighter (Figure 11, no. 1). It seems that these alterations affected the surface of the pieces prior to retouching. It is perfectly possible that they were produced during transport through the friction between the flint flakes or through contact with the container. Similar traces were obtained after a couple of days when the flint pieces were transported in a leather bag. These traces became even more marked after several weeks of transport (Rots, 2002, p. 67-68). It seems quite logical to assume transport if we admit that the exogenous flint materials used for the Armorican arrowheads were transported and stored in the form of flake blanks.

\subsection{Hafting traces}

On the occasion of ancient or more recent excavations, several archaeologists observed the survival of shafts, glue and binding threads (Chatellier, 1880; Le Pontois, 1890; Martin, 1904; Briard et al., 1982; Briard, 1984). The remnants of shaft bindings have disappeared since the excavation but the traces of glue were better preserved. These are visible to the naked eye in the form of brown-black deposits, sometimes associated with a brown film and can be identified as remnants of glue (Figure 12, no. 1 to 5). The aspect of these brown-black deposits is generally mat, sometimes greasy (Figure 12, no. 4). In most cases, this brownblack matter can be observed only occasionally on the surface of the arrowheads. Often, it is well-preserved in small cavities such as those left by hinge fractures (Figure 12, no 4). Preliminary analyses (infrared spectroscopy) carried out by Maxime Rageot (doctoral student, University of Nizza Sophia Antipolis) made it possible to confirm that the brown-black matter attached to the three arrowheads found in the burial of Prat-ar-Simon-Pella (Lannilis, 
Finistère) is indeed remnants of glue. The obtained signal matches that of plant tar or resin, perhaps of birch tar (personal communications with Martine Regert).
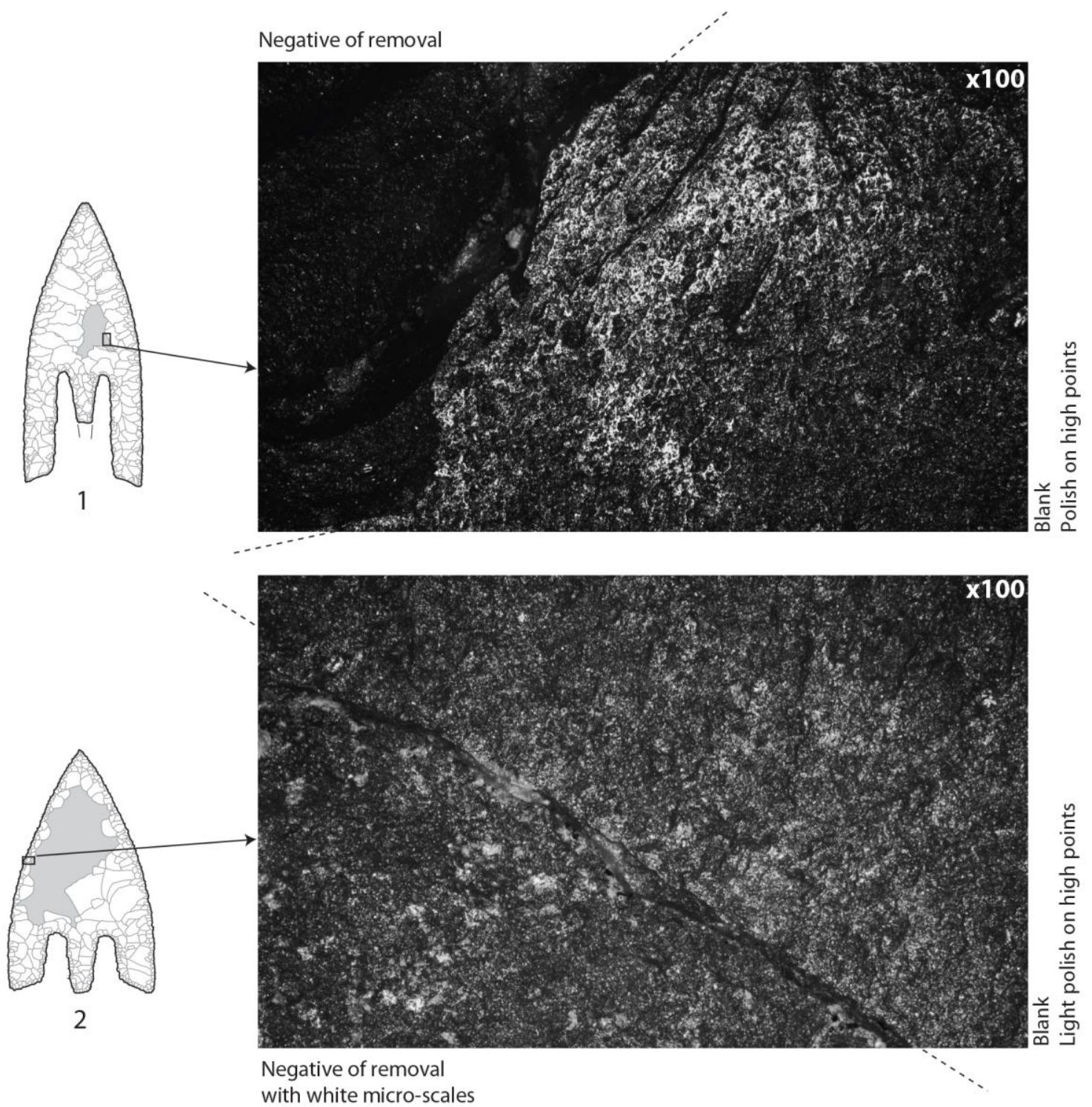

Bulbar face of the blank

$3 \mathrm{~cm}$

Figure 11. Use wear analysis of two Armorican arrowheads (photo C. Guéret; drawing C. Nicolas). 1. arrowhead from Prat-ar-Simon-Pella grave, Lannilis, Finistère; 2. arrowhead from Crec'h-Perros barrow, Perros-Guirec, Côtes-d'Armor.

Arrowheads exhibiting well-preserved remnants of glue are rare. In these cases, it can be stated that the brown-black matter covers not only the barbs (Figure 12, no. 2 and 5) but also the entire arrowhead: the remnants of glue are present close to or on the edges of the arrowheads (Figure 12, no. 1 and 2) and sometimes near to the tip (Figure 12, no. 3). Traces of glue are occasionally located in the centre of the piece (Figure 12, no. 3) or on a break (Figure 12, no. 4). This suggests that the break existed prior to the hafting of the arrowhead. Several examples of arrowheads with concave base dated to the Early/Middle Bronze Age in Denmark, Germany or the Netherlands seem to confirm this diagnosis: the glue covers the entire piece except for a strip 2 to $3 \mathrm{~mm}$ wide at the cutting edge (Piesker, 1937; Schünemann, 1975; Butler, 1990; Vang Petersern, 2008). Under the microscope remnants of glue can be 
recognised as thin crackled deposits or small pellets at the surface of the flint piece (Figure 13). On one glue deposit it was possible to observe linear and parallel marks possibly left by a non-braided binding thread (Figure 13, no. 3).

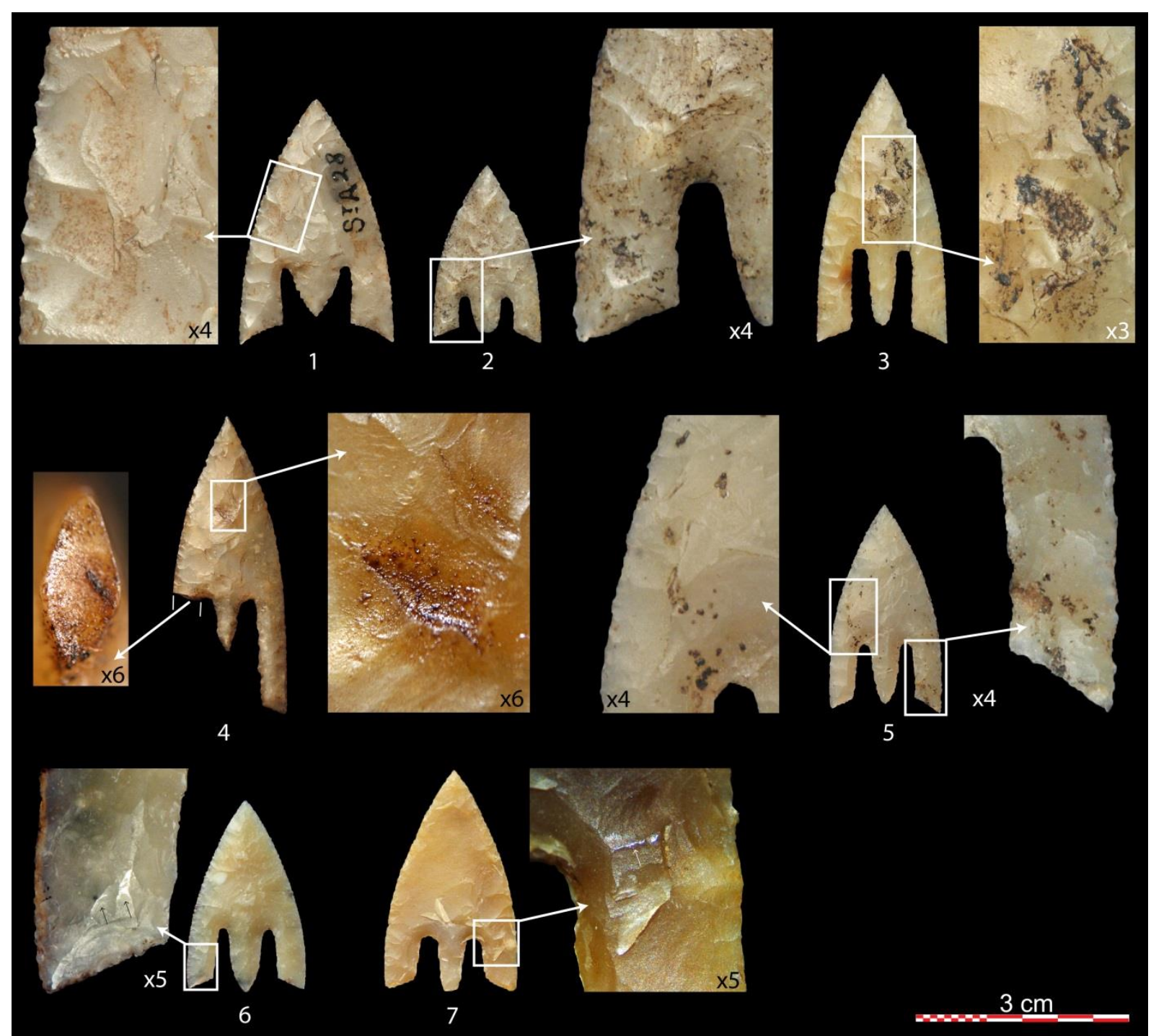

Figure 12. Macroscopic remains of glue (1 to 5) and bright spots (6 \& 7) on Armorican arrowheads (photo C. Nicolas). 1. arrowhead from Brun-Bras barrow, Saint-Adrien, Côtes-d'Armor; 2. arrowhead from Rumédon barrow, Ploumiliau, Côtes-d'Armor; 3. arrowhead from Tossen-Rugouec barrow, Prat, Côtes-d'Armor; 4. arrowhead from Graeoc 2 barrow, Saint-Vougay, Finistère; 5 \& 6. arrowheads from Kernonen barrow, Plouvorn, Finistère; 7. arrowhead from Crec'h-Perros barrow, Perros-Guirec, Côtes-d'Armor.

Almost all the arrowheads observed under the microscope bore very bright spots visible to the naked eye (Figure 12, no. 6 and 7). These are located on the high points, mainly on the arris of the negatives (Figure 14). Where they are particularly large, they may slightly recover the cavities (Figure 14, no. 1 and 3). They are located in the lower zone of the arrowhead, on the barbs and above, rarely exceeding half of the piece (Figure 14). Where they are well developed, the bright deposits are marked by short and large striations without polished ground. The striations are triangular with one end larger than the other. They are parallel but transversal with regard to the orientation of the arrowheads. These stigmata are often associated with blunted pieces. On a microscopic scale, these latter are systematically marked along the barbs and more particularly their denticulations (Figure 14, no. 2 and 4). They overflow only very little, except for the end of the barbs where they tend to cover the sides, 
associated with bright spots on the ridges of the removals (Figure 14, no. 2). They are very mat, coarse and often without polished component. In both cases, they cover the breaks, attesting that they were ancient (Figure 14, no. 4).
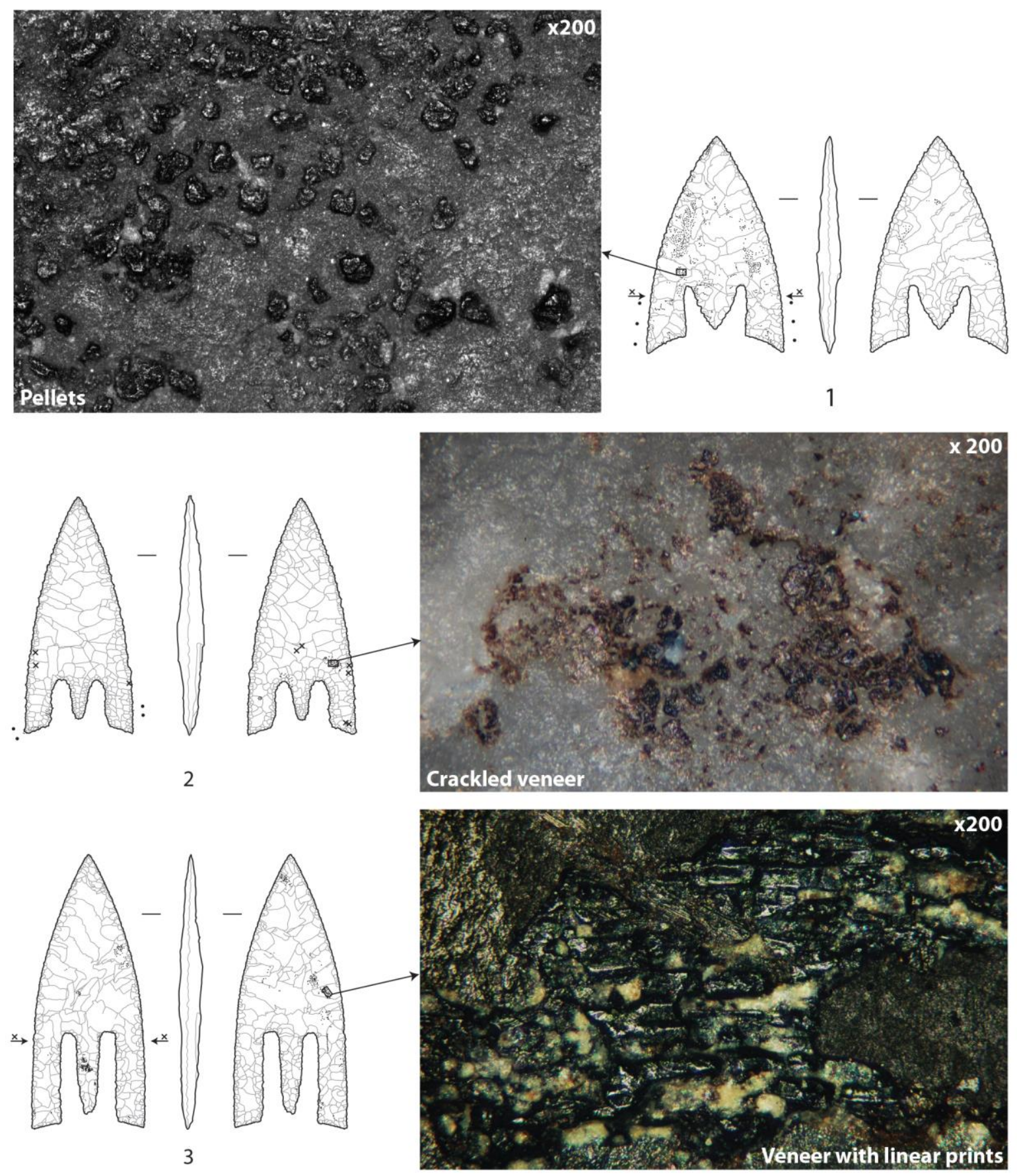

$\underset{x}{x} \ltimes$ High limit of bright spots $\quad \ldots$ Blunts

$\times \times$ Bright spots

$\because$ Adhesives remains

$3 \mathrm{~cm}$

Figure 13. Different aspects of glue remnants on Armorican arrowheads observed under the microscope (photo C. Guéret, C. Nicolas; drawings C. Nicolas). 1. arrowhead from Brun-Bras barrow, Saint-Adrien, Côtesd'Armor; 2. arrowhead from Crec'h-Perros-Guirec, Côtes-d'Armor; 3. arrowhead from Prat-ar-Simon-Pella grave, Lannilis, Finistère. 

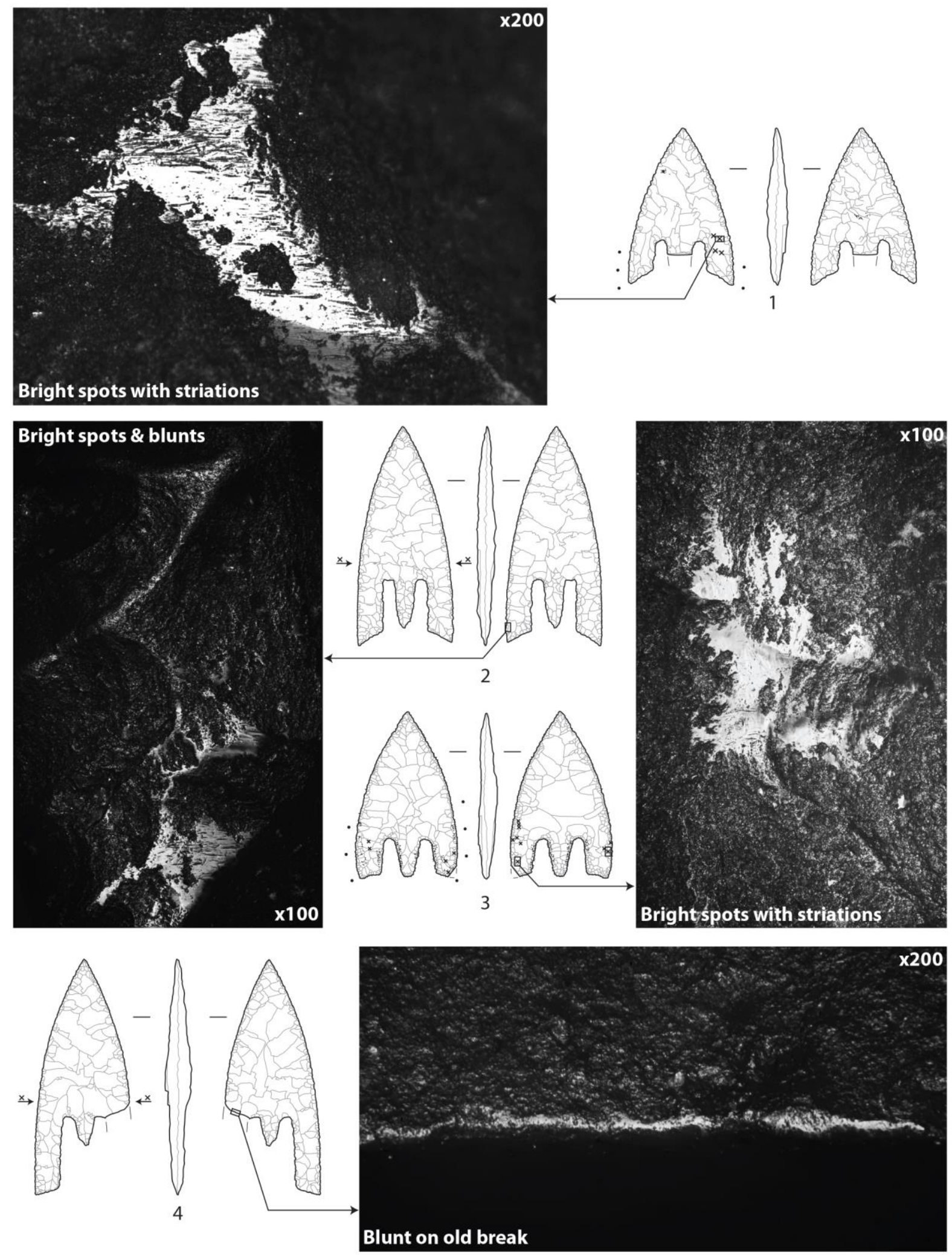

$\underset{x}{x}$ High limit of bright spots

... Blunts

$\times \times$ Bright spots

* Adhesives remains

$3 \mathrm{~cm}$

Figure 14. Bright spots and blunts on Armorican arrowheads (photo C. Guéret, C. Nicolas; drawings C. Nicolas). 1. arrowhead from Brun-Bras barrow, Saint-Adrien, Côtes-d'Armor; 2 and 4. arrowhead from Prat-ar-SimonPella grave, Lannilis, Finistère; 3. arrowhead from Crec'h-Perros-Guirec, Côtes-d'Armor. 
The bright spots are very similar to taphonomic alterations, often visible on archaeological material. Their distribution and the pattern of the striations, however, leave no doubt about their functional origin. These stigmata are closely related to blunted pieces and seem to occur during the same period of time (Figure 14, no. 2). Most probably they result from transversal and repeated movements of the implement in the hafting. Equally, the absence of a clear directional sign, the « smoothness » and the location of the blunting are rather indicative of progressive development, certainly linked to the binding threads. This assumption would imply quite a loose hafting which enabled the piece to move in a transversal manner according to the direction of the striations. It should therefore be admitted that the hafting of these arrowheads was of poor quality and not destined for efficient shots. This statement is supported by the fact that no diagnostic break indicative of an impact could be observed on the Armorican arrowheads. The hafting of the Armorican arrowheads thus seems to be symbolic rather than functional and lasted long enough to cause bright spots and blunts. This result is no less problematic as it is difficult to demonstrate by experimentation. Indeed, how can these traces be reproduced when it took several years, even tens of years, to form them?

According to the distribution of the bright spots and the blunt zones, the arrowheads were hafted with a thread passing around the barbs. In one case, this binding thread was applied on the glue (Figure 13, no 3). Glue was placed on the internal edges of the barbs and the tang but also on the external edges of the barbs. It is thought to totally cover the binding threads, the lower part of the arrowheads and sometimes their tip. With such a type of hafting, the long barbs of the Armorican arrowheads became perfectly invisible.

\subsection{Plant cutting, a practice both exceptional and anecdotic}

Plant gloss, unexpected on arrowheads, was recognised on four projectile points stemming from Crec'h-Perros (Perros-Guirec, Côtes-d'Armor). The polish is visible to the naked eye and on a microscopic scale it presents all the characteristics linked with the cutting of non-woody plants (Figure 15). It starts from the ridges of the negatives and stretches longitudinally into the removal cavities. It expands by 2 to $3 \mathrm{~mm}$ from the edges without clear limits. The polish is very bright with a uniform pattern, bulged, smooth and without striations. Its surface is pierced by many small holes. The nature of the traces and their distribution indicates that they were used to cut soft siliceous plant materials. The polish is large and cannot possibly stem from just occasional usage. Yet, it does not result from intensive use (several hours) as generally observed on the sickle implements.

The four arrowheads were used without hafting - or at least without binding - for the cutting of plants. As a matter of fact, the hafting traces overlay the sickle gloss (Figure 14). The polish, distributed from the barbs to the tip without reaching the ends could not have developed with the hafting that covered the barbs as we could reconstruct this for the Armorican arrowheads in general.

Several alternative hypotheses as to the origin of the sickle gloss were advanced but none of them is really convincing when set against the facts:

- technical polish for the brightening of the arrowheads: however, the gloss is only visible to the naked eye if it is closely examined and it does not seem important enough to be intentional; moreover, admitting such a hypothesis, one would expect polish on most or on all the arrowheads and not only on four specimens;

- shooting into haystacks (Menez and Hingant, 2010): this hypothesis, although attractive and highly suggestive, has to be excluded. The sickle gloss is cut by the hafting traces which indicates that the four arrowheads were used for the cutting of plants prior to their hafting in a shaft; 
- an arrow quiver made of plant materials: this hypothesis seems unlikely; indeed, if a quiver made of plant material had been in contact with an arrowhead, the polish should be present on the high points of the entire arrowhead (or at least on the parts that were not covered by the hafting) and not only on the edges.
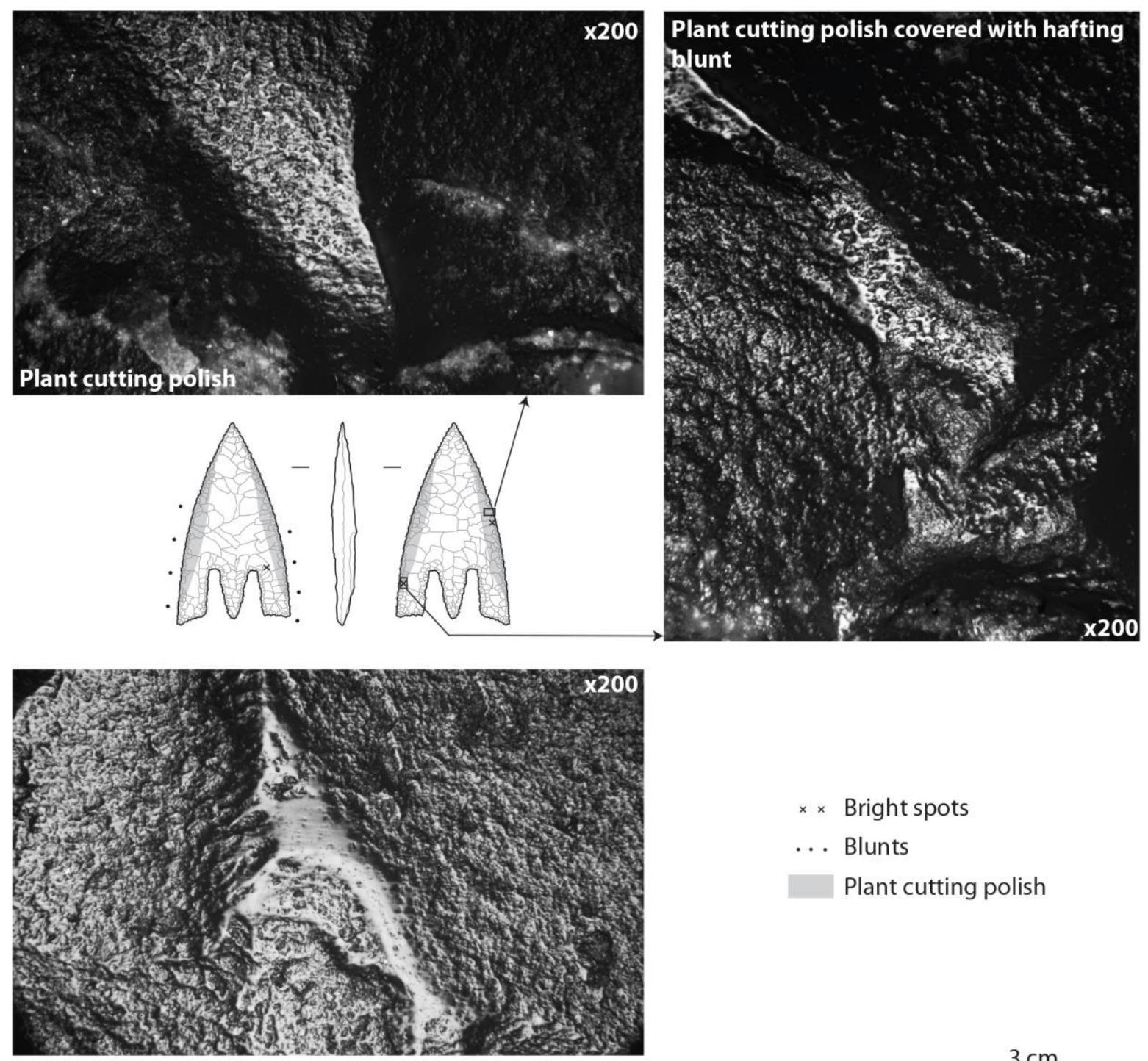

Plant cutting polish on another arrowhead

$\times \times$ Bright spots

... Blunts

Plant cutting polish

Figure 15. Plant cutting polish on arrowheads from Crec'h-Perros barrow, Perros-Guirec, Côtes-d'Armor (photo C. Guéret; drawing C. Nicolas).

Albeit surprising, plant cutting seems to be the most probable function. The occasional use of a cutting tool for the cutting of plants, however, should be excluded: the polish is welldeveloped and repeated on four arrowheads. The intensive use of arrowheads as sickles for cereal harvest cannot be taken into account either. The main, but currently unresolvable question is what kind of material was cut with these pieces. It is possible that these four arrowheads were used during manufacture for cutting the threads that served to fix the arrowheads on the shafts. Nonetheless, such an alienation of a highly symbolic object from its primary use is a significant action and it can be supposed that it took place within a ceremonial rite. In this regard, the gathering of plants with supposedly magic, psychotropic or medicinal virtues can be imagined. In any case, this practice remains anecdotal as it was 
observed on four arrowheads discovered at Crec'h-Perros only and not at all on those recovered from Brun-Bras or Prat-ar-Simon-Pella.

\section{Discussion}

The hypothesis that the Armorican arrowheads were strictly funerary objects (Giot et al., 1995, p. 67), knapped to be deposited in the grave is not valid. On the contrary, the analysis of the traces reveals that these artefacts were widely used before they became grave goods. The observations made under the microscope can be easily generalised on a macroscopic scale to the whole body of Armorican arrowheads. Hafting glue and bright spots are visible to the naked eye if they are closely examined (Figure 11), whilst blunted zones are evidenced by touch. These three aspects (glue, bright spots and blunts) are almost systematically encountered on the different series of Armorican arrowheads. There is evidence to suggest that all or at least a very large number of the arrowheads were loosely and poorly hafted; in such a way that use wear appeared (bright spots and blunts). Such an inoperative hafting together with the absence of impact marks makes these Armorican arrowheads non-functional objects, mounted on shafts for their exhibition only. This display is in itself contradictory because the long barbs of the arrowheads become invisible when the arrowhead is hafted. If our observations are right, what mattered was not that their owner displayed them but rather that it was known that he owned them.

In many respects, the Armorican arrowheads are prestige points alienated from their primary function. They were manufactured on exogenous flint, probably transported in the form of flake-blanks. Some of the pieces had served for the cutting of plants. More particularly, most of them were loosely hafted and never shot with a bow. Lastly, they were apparently dismantled and subsequently deposited in wooden boxes as grave goods. The description of the remains of the wooden box indeed indicates that they measured about thirty centimetres in length (Briard, 1970); which cannot possibly match the length of the arrows (43 to $210 \mathrm{~cm}$ ) documented in archaeological or ethnographic contexts (Cattelain, 2006).

The Armorican arrowheads, manufactured from exogenous flint by highly skilled knappers, certainly craftsmen, were apparently intended for display only. There is no doubt that these objects were reserved for the Early Bronze Age elite. These are in addition the most numerous and the most distinctive objects in the tombs of these chiefs. The Armorican arrowheads therefore can be considered as being insignia of power. These Early Bronze Age chiefs probably controlled the manufacturing of the arrowheads through the procurement of the raw material, by supporting the craftsmen and/or by controlling the circulation of the arrowheads. Such specialists attached to the elite also evoke an organisation close to the palatial workshops in the Eastern Mediterranean (Procopiou, 2006). Nonetheless, Cathy Lynne Costin (1991) stresses that the social context of the production (independent craftsmen or attached to the elite) has to be distinguished from its spatial organisation (dispersed or centralised). In this regard, the case of the Mycenaean arrowheads (1650-1050 before the Current Era) reveals the existence of craftsmen working for the elite without being under their physical control. In most cases, these arrowheads were discovered in the richest graves and in high numbers in the palaces of Mycenae and Pylos (Parkinson, 2007; Druart, 2010). However, none of the administrative texts (Linear B) ever mentions the work of the stone knappers in the palaces whilst these documents yield abundant details on craftsmen manufacturing bronze, weapons, chariots, textiles or scented oils (Kardulias, 2007). The control of the elite over the craft does not therefore require physical control of the craftsmen but was carried out by other means (economic power, moral authority?). Ultimately, it is possible that the knappers of Armorican arrowheads lived close to the Early Bronze Age elite or in a more dispersed manner. 


\section{Acknowledgements}

Translation was done by Karoline Mazurié de Keroualin. We would like to thank Stéphane Blanchet (Inrap GO), Michel Le Goffic (County Council of Finistère), Grégor Marchand (CNRS, UMR 6566) who enabled us to access the arrowheads of Crec'h-Perros, Prat-ar-Simon-Pella and Brun-Bras for our study. We are grateful to Philippe Forré (Inrap Grand-Ouest), Emmanuel Ghesquière (Inrap Grand-Ouest), Nicole Mallet (Centre d'Études et de Documentation Pressigniennes) and Jacques Pelegrin (CNRS, UMR 7055) for their help about raw materials. The analyses of remnants on the arrowheads stemming from Prat-arSimon-Pella were carried out by Maxime Rageot (University of Nizza-Sophia Antipolis) and by Martine Regert (CNRS, UMR7264) and we are grateful to them. Lastly, we would like to thank Alison Sheridan (National Museum of Scotland) for the radiocarbon dating of SaintFiacre funded by the Society of Antiquaries of London and Henri Gandois (doctoral student, University Paris 1) for the radiocarbon dating of Crec'h-Perros, funded by the Association Tumulus.

\section{References}

Apel, J. 2001, Daggers, knowledge and power: The social aspects of flint-dagger technology in Scandinavia 2350-1500 cal BC, Department of Archaeology and ancient History, Uppsala, 365 p.

Apel, J. 2008 - Knowledge, Know-How and Raw Material - The Production of Late Neolithic Flint Daggers in Scandinavia, Journal of archaeological Method and Theory, 15, 1: 91111. doi:10.1007/s 108 16-007-9044-2

Aubry, T. 1991, L'exploitation des ressources en matières premières lithiques dans les gisements solutréens et badegouliens du bassin versant de la Creuse, France, $\mathrm{PhD}$ thesis, University of Bordeaux I, Bordeaux, 327 p. (in French) ("Exploitation of lithic raw materials in Solutrean and Badegoulian deposits of the Creuse drainage basin, France")

Bailly, M. 2014, Discordance des temps, concordance des espaces ? Remarques sur les armatures de flèches en contexte campaniforme. De l'Arc jurassien à l'Isthme européen, in R.-M. Arbogast, A., Greffier-Richard (eds.), Entre archéologie et écologie, une Préhistoire de tous les milieux. Mélanges offerts à Pierre Pétrequin. Annales Littéraires de l'Université de Franche-Comté 928, série «Environnement, sociétés et archéologie » 18, Presses universitaires de Franche-Comté, Besançon: 355-385. (in French)

("Discordance of times, concordance of spaces? Remarks on arrowheads in Bell Beaker context. From the Jura to European Isthmus")

Bertrand, A. 1891, Nos origines, la Gaule avant les Gaulois, d'après les monuments et les textes, éd. Ernest Leroux, Paris, 349 p. (in French) ("Our origins, Gaul before the Gauls, according to the monuments and texts")

Blanchet, S. 2005, La tombe du Bronze ancien de Crec'h Perros à Perros Guirec, 22 : les premiers résultats, Bulletin de l'Association pour la Promotion des Recherches sur l'Âge du Bronze, 2: 27-29. (in French) ("The Early Bronze Age grave of Crec'h Perros at Perros Guirec, Côtes-d'Armor: first results")

Briard, J. 1970, Un tumulus du Bronze ancien : Kernonen en Plouvorn (Finistère), L'Anthropologie, 74: 5-56. (in French) ("An Early Bronze Age barrow: Kernonen at Plouvorn (Finistère)") 
Briard, J. 1978, Das Silbergefäss von Saint-Adrien, Côtes-du-Nord, Archäologisches Korrespondenzblatt, 8: 13-20. (in German) ("The silver beaker from Saint-Adrien, Côtes-du-Nord")

Briard, J. 1984, Les tumulus d'Armorique, L'Âge du Bronze en France 3, Picard, Paris, 304 p. (in French) ("The barrows of Armorica")

Briard, J., \& Giot, P.-R. 1956, Typologie et chronologie du Bronze ancien et du Premier Bronze moyen en Bretagne, Bulletin de la Société préhistorique française, 53(7-8): 363373. (in French) ("Typology and chronology of the Early and Middle Bronze Age in Brittany") doi:10.3406/bspf.1956.3348

Briard, J., Cabillic, A., Marguet, A., \& Onnée, Y. 1982, Les fouilles de Kersandy à Plouhinec (Finistère) : une tombe du Bronze Ancien à « déesse-mère » néolithique, Bulletin de la Société archéologique du Finistère, 110: 17-39. (in French) ("The Kersandy excavations at Plouhinec (Finistère): an Early Bronze Age grave with Neolithic « Mother Goddess »")

Butler, J.J. 1990, Bronze Age Metal and Amber in the Netherlands, Palaeohistoria, 32: 47110.

Cattelain, P. 2006, Apparition et évolution de l'arc et des pointes de flèches dans la Préhistoire européenne (Paléo-, Méso-, Néolithique), In: Catene operative dell'arco preistorico, Atti dell'incontro di archeologia sperimentale, Fiavè - S. Lorenzo in Banale 30/31 agosto - 1 settembre 2002 (Bellintani, P., \& Cavulli, F., eds.), Giunta della Provincia Autonoma di Trento, Soprintendenza per i Beni Archeologici, Trento: 45-66. (in French) ("Appearance and evolution of bows and arrows during European Prehistory")

du Chatellier, P. 1880, Exploration du tumulus du Kerhué-Bras en Plonéour-Lanvern, Matériaux pour l'Histoire primitive et naturelle de l'Homme, 2(11): 289-298. (in French) ("Exploration of the Kerhué-Bras barrow at Plonéour-Lanvern") Stable URL: http://www.jstor.org/stable/41735485

Costin, C.L. 1991, Craft Specialization: Issues in Defining, Documenting, and Explaining the Organization of Production, In: Archaeological Method and Theory (Schiffer, M.B., ed.), the University of Arizona Press, Tucson, 3: 1-56.

Druart, C. 2010, Production and function of stone arrowheads in the Mycenaean civilization: A techno-morphological and functional approach, In: Lithic technology in metal using societies, Proceedings of a UISPP Workshop, Lisbon, September 2006 (Eriksen, B.V., ed.), Jutland archaeological Society Publications 67, Jutland archaeological Society Højbjerg: 143-155.

Fouéré, P. 1994, Les industries en silex entre Néolithique moyen et Campaniforme dans le nord du Bassin Aquitain: Approche méthodologique, implications culturelles de l'économie des matières premières et du débitage, $\mathrm{PhD}$ thesis, University of Bordeaux 1, Bordeaux, 2 vol., 551 p. (in French) ("Flint industries between the Middle Neolithic and the Bell Beaker in the northern part of the Aquitaine basin: methodological approach, cultural implication of raw materials and débitage economy")

du Gardin, C. 1996, L'ambre en France au Bronze Ancien : données nouvelles, In: Cultures et Sociétés du Bronze Ancien en Europe, Actes du 117e Congrès national des Sociétés historiques et scientifiques, Clermont-Ferrand, 1992 (Mordant, C., \& Gaiffe, O., eds.), 
éd. du Comité des Travaux historiques et scientifiques, Paris: 189-195. (in French) ("Amber in France during the Early Bronze Age: new data")

Giot, P.-R., Briard, J., \& Pape, L. 1995, Protohistoire de la Bretagne, éd. Ouest-France, Rennes, 422 p. (in French) ("Protohistory of Brittany")

Hafner, A., \& Suter, P.J. 2003, Vom Endneolithikum zur Frühbronzezeit: Wandel und Kontinuität zwischen 2400 und 1550 v. Chr., Archäologisches Korrespondenzblatt, 33(3): 325-344. (in German) ("From the Final Neolithic to the Early Bronze Age: change and continuity between 2400 and 1550 BC")

Inizan, M.-L., Tixier, J. 2000, L'émergence des arts du feu : le traitement thermique des roches siliceuses, Paléorient, 26, 2: 23-36. (in French) ("Emergence of the arts of fire: the heat treatment of siliceous rocks") doi:10.3406/paleo.2000.4707

Kardulias, P.N. 2007, Flaked Stone and the Role of the Palaces in the Mycenaen World System, In: Rethinking Mycenaean Palaces II, revised and expanded second edition (Galaty, M.L., \& Parkinson, W.A., eds.), University of California Monograph 60, Cotsen Institute of Archaeology, Los Angeles: 102-113.

Keeley, L. H. 1980, Experimental determination of stones tool uses: a microwear analysis, University of Chicago, Chicago, $212 \mathrm{p}$.

Le Goffic, M. 1995, Le caveau de l'âge du bronze de Kerfichaux en Lannilis (Finistère), Bulletin de la Société archéologique du Finistère, 124: 35-53. (in French) ("The Bronze Age burial of Kerfrichaux, Lannilis (Finistère)")

Le Goffic, M., Nallier, R. 2008, Fouille d'un caveau du Bronze ancien à Lannilis (Finistère), Journée du «CreAAH»: Archéologie, Archéosciences, Histoire, Rennes, 24 Mai 2008, University of Rennes 1, Rennes: 41-43. (in French) ("Excavation of an Early Bronze Age grave at Lannilis (Finistère)")

Le Pontois, L. 1890, Le tumulus de Cruguel en Guidel, Revue archéologique, 16: 304-338. (in French) ("The Cruguel barrow at Guidel")

Lukis, J.W. 1886, An account of the opening of a tumulus of the Bronze Age period, etc., in the department of Finistère, France, 1884, Transactions of the Cardiff Naturalists' Society, 18: 12-16.

Marchand, G. 2012, Différences de potentiel géologique entre massifs cristallins et bassins sédimentaires, In: Roches et sociétés de la Préhistoire entre Massifs cristallins et Bassins sédimentaire (Marchand, G., \& Querré, G., eds.), Presses universitaires de Rennes (Coll. Archéologie \& Culture), Rennes: 9-28. (in French) ("Differences of geological potential between crystalline massifs and sedimentary basins")

Martin, A. 1904, Fouille du tumulus du Rumédon en Ploumiliau, Côtes-du-Nord, Bulletin de la Société archéologique du Finistère, 31: 128-154. (in French) ("Excavation of the Rumédon barrow at Ploumiliau, Côtes-du-Nord")

Martin, A., \& Berthelot du Chesnay, C. 1899, Exploration du tumulus de Tossen-Maharit, commune de Trévérec, Bulletin de la Société d'Émulation des Côtes-du-Nord, 37: 5-36. (in French) ("Investigations into the Tossen-Maharit barrow at Trévérec").

Martin, A., \& Prigent 1907, Le Mouden-Bras en Pleudaniel, Bulletin de la Société archéologique du Finistère, 34: 146-178. (in French) ("The Mouden-Bras at Pleudaniel") 
Masson, A. 1981, Pétroarchéologie des roches siliceuses. Intérêt en Préhistoire, $\mathrm{PhD}$ thesis, University of Lyon 1, 90 p. (in French) ("Petroarchaeology of siliceous rocks. Interest in Prehistory)

Ménez, Y., Hinguant, S., (2010) - Fouilles et découvertes en Bretagne, Ouest-France, Rennes, 143 p. (in French) ("Excavations and discoveries in Brittany").

Needham, S. 2000, Power Pulses Across a Cultural Divide: Cosmologically Driven Acquisition Between Armorica and Wessex, Proceedings of the prehistoric Society, 66: 151-207.

Needham, S. 2009, Encompassing the Sea: 'Maritories' and Bronze Age maritime interactions, In: Bronze Age Connections: Cultural Contact in Prehistoric Europe (Clark, P., ed.), Oxbow Books, Oxford: 12-37.

Needham, S., Lawson, A.J., \& Woodward, A. 2010, 'A Noble Group of Barrows': Bush Barrow and the Normanton Down Early Bronze Age Cemetery Two Centuries on, The Antiquaries Journal, 90: 1-39.

Nicolas, C. with contributions of Pailler, Y., Stephan, P., Denis, S., Quillivic, M., Kergourlay, A. and the collaboration of Masei, I., Ripoche, J. 2010, Programme de prospections " Bronze ancien », rapport $n^{\circ}$ 2: Rapport de prospection thématique à PlounévezLochrist, Saint-Vougay et leurs environs (29), Opération $n^{\circ}$ 2010-211, autorisation préfectorale du 17 février 2010, Service régional de l'Archéologie, Rennes, 129 p. (in French) ("Bronze Age field survey program, report no. 2: report on field survey in Plounévez-Lochrist, Saint-Vougay and their surroundings, Finistère, Operation no. 2010-211, prefectoral authorisation of the $24^{\text {th }}$ February 2010")

Nicolas, C. 2011a, Artisanats spécialisés et inégalités sociales à l'aube de la métallurgie : les pointes de flèches de type armoricain dans le nord du Finistère, Bulletin de la Société préhistorique française, 108(1): 93-125. (in French) ("Specialized crafts and social inequality at the dawn of metallurgy: arrowheads of Armorican type in the northern Finistère")

Nicolas, C. with contributions of Gandois, H., Kergourlay, A., Le Carlier, C., Pailler, Y., Stephan, P. and the collaboration of Javel, J.-B., Quillivic, M., Verhaeghe, M. 2011b, Programme de prospections «Bronze ancien », rapport $n^{\circ}$ 3: Rapport de prospection thématique à Lannilis et ses communes environnantes (29), Opération $n^{\circ} 2011-213$, autorisation préfectorale du 24 avril 2011, Service régional de l'Archéologie, Rennes, 102 p. (in French) ("Bronze Age field survey program, report no. 3: report on field survey in Lannilis and its surroundings, Finistère, Operation no. 2011-213, prefectoral authorisation of the $24^{\text {th }}$ April 2011")

Nicolas, C. 2012, Des pierres précieuses ? Les pointes de flèches du Campaniforme et de l'âge du Bronze ancien en Bretagne (2500-1700 avant notre ère), In: Roches et sociétés de la Préhistoire entre Massifs cristallins et Bassins sédimentaire (Marchand, G., \& Querré, G., eds.), Collection Archéologie \& Culture, Presses universitaires de Rennes, Rennes: 205-219. (in French) ("Precious stones ? Bell Beaker and Early Bronze Age arrowheads from Brittany (2500-1700 BC)")

Nicolas, C. 2013, Symboles de pouvoir au temps de Stonehenge : les productions d'armatures de prestige de la Bretagne au Danemark (2500-1700 av. J.-C.), $\mathrm{PhD}$ thesis, University of Paris 1 Panthéon-Sorbonne, 2 vol., 1054 p. (in French) ("Symbols of power at the time of Stonehenge: productions of prestigious arrowheads from Brittany to Denmark (2500-1500 BC)") 
Nicolas, C., Pailler, Y., Stephan, P., \& Gandois, H. 2013, Les reliques de Lothéa (Quimperlé, Finistère) : une tombe aux connexions atlantiques entre Campaniforme et âge du Bronze ancien, Gallia Préhistoire, 55: 181-227. (in French) ("The relics of Lothéa (Quimperlé, Finistère): a grave with Atlantic connections between the Bell Beaker and Early Bronze Age")

Pailler, Y., Stephan, P., Gandois, H., Nicolas, C., Sparfel, Y., Tresset, A., Donnart, K., Dréano, Y., Fichaut, B., Suanez, S., Dupont, C., Le Clézio, L., Marcoux, N., Pineau, A., Salanova, L., Sellami, F., Debue, K., Josselin, J., Dietsch-Sellami, M.-F. 2011, Évolution des paysages et occupation humaine en mer d'Iroise (Finistère, Bretagne) du Néolithique à l'âge du Bronze, Norois, 220: 39-68. (in French) ("Landscapes evolution and human settlement in the Iroise sea (Finistère, Brittany) from Neolithic to Bronze Age") doi:10.4000/norois.3662

Parkinson, W.A. 2007, Chipping Away at a Mycenaean Economy: Obsidian Exchange, Linear B, and "Palatial Control" in Late Bronze Age Messenia, In: Rethinking Mycenaean Palaces II, revised and expanded second edition (Galaty, M.L., \& Parkinson, W.A., eds.), University of California Monograph 60, Cotsen Institute of Archaeology, Los Angeles: 87-101.

Pelegrin, J. 2002, La production des grandes lames de silex du Grand-Pressigny, In: Matériaux, productions, circulations du Néolithique à l'Age du Bronze : séminaire du Collège de France (Guilaine, J., ed.), Errance, Paris: 131-150. (in French) ("Production of long blades made of Grand-Pressigny flint")

Pelegrin, J. 2004, Sur les techniques de retouche des armatures de projectile, In: Les derniers magdaléniens d'Etiolles : perspectives culturelles et paléohistoriques (l'unité d'habitation Q31) (Pigeot, N., ed.), suppl. à Gallia Préhistoire 37, CNRS Editions, Paris: 161-166. (in French) ("About techniques of retouch of projectile points")

Piesker, H. 1937, Funde aus der ältesten Bronzezeit der Heide, Nachrichten aus Niedersachsens Urgeschichte, 10: 120-143. (in German) ("Early Bronze Age finds from the heathland")

Prigent 1880, Exploration du tumulus de Porz-ar-Saoz, en Trémel, Bulletin de la Société d'Émulation des Côtes-du-Nord, 17: 173-194. (in French) ("Investigations into the Porz-ar-Saoz barrow at Trémel")

Prigent 1881, Fouille du grand tumulus de Tossen-Kergourognon en la commune de Prat, Côtes du Nord, Bulletin de la Société d'Émulation des Côtes-du-Nord, 19: 15-31. (in French) ("Excavation of the big barrow of Tossen-Kerougorognon at Prat, Côtes du Nord")

Primault, J. 2003, Exploitation et diffusion des silex de la région du Grand-Pressigny au Paléolithique, $\mathrm{PhD}$ thesis, University of Paris X, Nanterre, 362 p. (in French) ("Exploitation and diffusion of the flints from the Grand-Pressigny region during the Palaeolithic")

Procopiou, H. 2006, Artisans et artisanat dans le monde égéen protohistorique : état de la question, Techniques \& Culture, 46-47: 303-323. (in French) ("Craftsmen and crafts in the Protohistoric Aegean world")

Rots, V. 2002, Bright spots and the question of hafting, Anthropologica et Praehistorica, 113: 61-72. 
Schünemann, D. 1975, Die ältere und die mittlere Bronzezeit im Kreis Verden, Nachrichten aus Niedersachsens Urgeschichte, 44: 35-85. (in German) ("The Early and Middle Bronze Age in the Verden district")

Stafford, M. 2003, The parallel-flaked flint daggers of Late Neolithic Denmark: an experimental perspective, Journal of archaeological Science, 30: 1537-1550. doi:10.1016/S0305-4403(03)00043-8

Vang Petersen, P. 2008, Flint fra Danmarks oldtid, Forlaget Museerne.dk, København, 154 p. (in Danish) ("Flint from prehistoric Denmark")

Voruz, J.-L. 1996, La chronologie absolue du Bronze Ancien, In: Cultures et Sociétés du Bronze Ancien en Europe, Actes du 117e Congrès national des Sociétés historiques et scientifiques, Clermont-Ferrand, 1992 (Mordant, C., \& Gaiffe, O., eds.), éd. du Comité des Travaux historiques et scientifiques, Paris: 97-164. (in French) ("Absolute chronology of the Early Bronze Age") 